XIII.

Aus der medicinischen Abtheilung des städt. Krankenhauses Altona

(Director: Prof. Dr. Umber).

\title{
Ueber Iso- und Autohämolysine im menschlichen Blutserum.
}

\author{
Von \\ Dr. M. Bürger, \\ Assistent. \\ (Mit 1 Curre im Text.)
}

Ueber Hämolysine in den Organen des menschlichen und thierischen Körpers, seinen Se- und Excreten, liegen zahlreiche Beobachtungen vor. So konnte Noguchi (1) aus verschiedenen Organen thermostabile Hämolysine gewinnen; im Pankreassaft wurden solche nachgewiesen [Tarrasewitz (2), Friedemann (3)], im Kot [Külbs (4), Bloch (5), Grafe und Römer $(6,7)$ ] und in der Darmschleimhaut Gesunder und Kranker [Berger und Tsuchiya (8)]. Während die eben erwähnten Hämolysine zum Theil chemisch definirte Körper (Oelsäure) sind, zum Theil in die biochemisch wohl abgrenzbare Gruppe der Lipoide gehören, gilt das nicht für alle Hämolysine des Serums. Wenn man die nur gegen die Blutkörperchen fremder Thierspecies wirksamen Stoffe (Normalamboceptoren) ausnimmt, bleiben zwei Gruppen von Hämolysinen des menschlichen Serums übrig, von denen die eine nur nach vorheriger Abkühlung (Kälteamboceptoren), die andere ohne primäre Kältebehandlung wirksam wird. Ueber die chemische Natur der bis jetzt nachgewiesenen iso- und autohämolytischen Stoffe des menschlichen Serums ist wenig bekannt. Uebereinstimmung herrscht nach den Arbeiten von Donath und Landsteiner $(9,10)$, Meyer and Emmerich (12), Moro Noda und Benjamin (13), Grafe und Leo Müller (14) nur darüber, dass der bei der paroxysmalen Hämoglobinurie als wirksam nachgewiesene Körper complexer Natur ist, während man über die Natur der bei anderen Erkrankungen im Serum nachgewiesenen Hämolysine noch nicht einig ist. Die Beobachtung eines typischen Falles von paroxysmaler Hämoglobinurie gab die Anregung auf der hiesigen Abtheilung ausgedehnte Untersuchungen über diese Frage anzustellen, insbesondere darüber, ob sich vielleicht weit häufiger als bisher bekannt Lysine der ersten und zweiten Gruppe im Serum bei verschiedenen Krankheiten nachweisen lassen und ob deren Nachweis klinische Bedeutung hat.

Wegen der grossen biologischen Wichtigkeit, die der Nachweis von Immunsubstanzen gegen zum Verfall kommendes körpereigenes Gewebe 
haben würde, ist immer wieder versucht worden, durch solche Vorgänge entstehende Reactionsproducte zu demonstriren. Ehrlich (24) befasst sich in seiner dritten Mitheilung über Hämolysine eingehend mit der Frage der Iso- und Autohämolysinbildung im thierischen Körper. Beiläufig erwähnt er, welche Bedeutung es haben würde, wenn z. B. bei acuter gelber Leberatrophie Hepatolysine entständen. Wir haben uns in eigenen Versuchen an einem einschlägigen Fall nicht von dem Vorhandensein solcher Reactionskörper überzeugen können:

Bei einem Fall von acuter gelber Leberatrophie, bei dem Leucin, Tyrosin und Cystin im Harn nachweisbar waren, wurde durch Venenpunlition Serum entnommen. In dieses Serum wurden von Menschen stammende Leberstückchen geworfen, die von einem acut $\mathrm{zu}$ Grunde gegangenen Individuum sofort nach dem Tode gewonnen wurden. Die Leberstückchen wurden mit dem Doppelmesser und mit dem Gefriermikrotom unter sterilen Cautelen in feine Stücke zerlegt, gewogen und in das fragliche und mehrere andere Controlsera geworfen, 12 Stunden bei $37^{\circ}$ bebrütet und im Serum nach Abcentrifugiren der Leberstïokchen Stickstoff bestimmungen gemacht. Ebenso wurden aus den Controlseren und aus dem Serum, in das keine Leberstückchen geworfen waren, N-Bestimmungen angestellt. Es wäre bei einem wirksamen Isobepatolysin eine erhöhte Stickstoffquote in den Röhrchen zu erwarten gewesen, in denen menschliche Leber mit dem Serum der acuten gelben Leberatrophie zusammengebracht war (Röhrchen A). Das war aber, wie nachstehendes Protokoll lehrt, nicht der Fall.

Röhrchen A. $9 \mathrm{ccm}$ Serum von acuter gelber Leberatrophie $+1 \mathrm{~g}$ menschlicher Leber. Nach 12 stündigem Verweilon bei $37^{\circ}$ in $2 \mathrm{ccm}$ ahcentrifugirtem Serum: $0,02 \mathrm{~N}$.

Röhrchen a. $2 \mathrm{ccm}$ Serum von acuter gelber Leberatrophio allein. Darin nach 12 stündigem Verweilen bei $37^{0}: 0,02 \mathrm{~N}$.

Röhrchen B. $9 \mathrm{ccm}$ Normalserum (Arthritis def.) + $1 \mathrm{~g}$ menschlicher Leber. Darin nach 12 stündigem Verweilen des Gemisches in $2 \mathrm{ccm}$ abcentrifugirtem Serum: $0,027 \mathrm{~N}^{1}$ ).

Röbrchen b. Nur $2 \mathrm{ccm}$ Normalserum. Darin nach 12 stündigem Verweilen bei $37^{0}: 0,021 \mathrm{~N}$.

Dio Differenzen liegen innerhalb der Feblergrenzen.

Ueber die klinische Bewerthung der in der Nierenpathologie eine Zeitlang eine Rolle spielenden Nephrolysine haben wir keine eigenen Beobachtungen. Ehrlich kommt in der erwähnten Arbeit zu dem Resultat, $\eta$ dass eine dauernde Schädigung des Organismus durch reactive Producte im Allgemeinen nicht eintreten wird, sondern dass erst, wenn die internen Regulationsvorrichtungen nicht mehr intact sind, schwere Gefahren auftreten können". Während die meisten Untersuchungen, die auf den Nachweis von Autolysinen - sowohl bei Krankheiten entstandener als im Experiment erzeugter - gerichtet wurden, zu negativen Ergebnissen führten [Moss (25) u. A.], ist von Guillain und la Roche (27) über 2 Fälle von meningealen Blntungen berichtet, bei denen Isohämolysine im Liquor und im Serum aufgetreten sein sollen. Ebenso berichtet Blasi (15) über Hämolysine und autohämolytische Stoffe im Serum von Malariakranken. Steyskal (26) findet bei Fällen von perniciöser Anämie nnd hämo-

1) Die höhere N-Zahl ist durch Bakterienentwickelung bedingt. 
Jytischem Icterus schwach wirksame Hämolysine. Ueber die Autoimmunisation gegen zum Zerfall kommende Erythrocyten können wir nur soviel sagen, dass wir die interessante Beobachtung von Guillain - Auftreten von Autohämolysine nach apoplectischen Blutungen - an 10 Fällen von Apoplexie nicht bestätigen konnten. Dagegen gelang es uns in zahlreichen anderen Fällen Isobämolysine und in 3 Fällen Autohämolysine nachzuweisen. Ueber das Auftreten dieser Körper und über den klinischen und diagnostischen Werth ihres Nachweises soll im Folgenden berichtet werden.

\section{Ueber complexe Hämolysine (Kälteamboceptoren) bei paroxysmaler Hämoglobinurie und latente Hämolysinämie (hämolytische Diathese).}

Nachdem Donath und Landsteiner das eigenthümliche Verhalten des Serums zu den rothen Blutkörpern bei Fällen von paroxysmaler Hämoglobinurie (9) und in einer späteren Arbeit bei einigen Fällen von Paralyse hingewiesen hatten, nämlich dass das Serum zugehörige und fremde menschliche rothe Blutkörper nach vorheriger Abkühlung und späterer Erwärmung in vitro zu lösen im Stande ist, ist dieser Befund von den verschiederısten Seiten bestätigt worden. Da unter den neueren Beobachtungen sich einige finden, in denen bei Abwesenheit aller luetischen Zeichen sich eine stark positive Wassermann-Luesreaction zeigte und auch wir einen einschlägigen Fall dieser Art beobachten konnten, legten wir uns von neuem die Frage vor, ob nicht doch unter dem serologischen Material sich Fälle fänden, die bei positiver Wassermann-Luesreaction und bei positivem Ausfall des Kälte-Wärmeversuchs wohl auf eine bestehende Bluterkrankung, nicht aber auf eine überstandene Lues hinwiesen.

Wir fanden unter 272 Fällen, die wir nach Donath-J andsteiner untersuchten, 3 Fälle, die ganz wie Donath und Landsteiner es beschrieben haben reagirten. Der erste Fall betrifft einen Fall typischer paroxysmaler Hämoglobinurie, der bei +++ positiver Wassermann-Lnesreaction kein einziges klinisches noch anamnestisches Zeichen einer überstandenen Lues hatte. Dieser sei zunächst erwähnt:

42 Jahre alter Arbeiter H. Aufgenommen am 25. 10. 1910. Nie krank gewesen bis 1886, damals schwerer Gelenlrheumatismus. Von 1888-1891 zur See gefahren, seit 1891 in Hamburg als Hafenarbeiter. Seit 1904 bei nasskalten Wetter bäufig Anfälle, die mit Schüttelfrost und Beschwerden beim Urinlassen einhergehen. Bei jeder Attacke Entleerung eines schwarzbraunen Urins. Nach einer Stunde sind Schmerzen und Fieber abgeklungen, vollkommenes Wohlbefinden. Auftreten der Anfälle abhängig von der Witterung. Durch feuchtes nebeliges Wetter wird dasselbe begünstigt. In letzter Zeit fast täglich Anfälle gehabt.' Pat. hat Gonorrhoe im jugendlichen Alter überstanden, aber niemals einen Schanker gehabt; lebt in geordneten Verhältnissen und hat eine gesunde Frau und 3 gesunde Kinder.

Status praesens: Kräftig gebauter Mann, gesunde Hautfarbe, guter Ernährungszustand, kein Zeichen überstandener oder bestehender Lues.

Herzmaasse im Orthodiagramm: Medianabstand rechts 4,4, links 10,3. Spitzenstoss im fünften Intercostalraum wenig hebend; leises diastolisches Geräusch (acute Polyarthritis 1886!) über der Aorta. Pulsus altus et celcr.

A,bdomen: Nirgends Druckempfindlichkeit. Leber deutlich palpabel, glattrandig.

Milz percutorisch gross, nicht palpabel. 
Der Urin ist fast schwarz, entbält viel Eiweiss und reichlich granulirte Cylinder, viel Hämoglobin (spectroskopisch und chemisch nachgewiesen). Keine rothen Blutkörper oder Blutkörperschatten.

Blutuntersuchung: Wassermann-Luesreaction positiv. Das Serum bämolysiert die eigenen und frenden Blutkörper nach vorheriger Abkühlung auf $0^{0}$ obne Zusatz fremden Complements. Sofort bei $37^{0}$ bebrütet tritt in dem BlutkörperchenSerumgemisch keine Hämolyse ein. Deutliche Hämolyse war noch zu erkennen bei $0,3 \mathrm{ccm}$ Serum, 1,0 ccm 5proc. Menschenblutlö̈rperaufschwemmung; $0,7 \mathrm{ccm} \mathrm{NaCl}$. Die Versuche wurden zu den verschiedensten Zeiten im Laufe von 2 Monaten wiederholt, stets mit gleichem Erfolg. Complementverarmung konnte nie gezeigt werden, auch nicht nach den Anfällen. Experimentell einen Anfall auszulösen, bot sich keine Golegenheit.

Nach dem Gesagten handelt es sich also um einen Fall von typischer paroxysmaler Hämoglobinurie, der uns deswegen casuistisch bemerkenswerth erscheint, weil eine Lues so gut wie ausgeschlossen werden konnte und das Serum trotzdem constant eine ++++ positive Wassermann'sche Reaction ergab.

Weit interessanter und principieller wichtig ist ein zweiter Fall, zu dessen genauester klinischer Beobachtung wir durch den positiven Ausfall des Donath-Landsteiner'schen Versuchs geführt wurden.

Am 4. 11. 1910 wurde der 31 Jahre alte $A$ rbeiter 0 . T. auf die innere $A b$ theilung aufgenommen. Er giebt an, als Kind nicht krank gewesen zu sein, 2 Jahre als Infanterist gedient und sich bis zum 4. 9. 1910 stets einer guten Gesundheit erfreut zu haben. An diesem Tage stürzte er von einem Wagen herunter und schlug mit der linken Seite und Schulter auf eine Holzschwelle auf. Es stellten sich sofort Schmerzen in der linken Seite ein ohne Bewusstseinsverlust. Nach einigen Minuten konnte T. sich wieder erheben und ohne fremde Hilfe nach Hause gehen. Einen Arbeitsversuch am folgenden Tage musste ' $\mathrm{T}$. wieder aufgeben, wegen heftiger Schmerzen im Rücken und in der Seite. Nach fünftägiger (antirheumatischer) Behandlung konnte er jedoch die Arbeit wieder aufnehmen und bis heute fortsetzen. Nachdem in der Zwischenzeit geringe Rückenschmerzen fortbestanden hatten, stellte sich am 4. November plötzlich unter Schüttelfrost ein Schwindelanfall ein mit Uebelkeit und Erbrechen. Pat. ging nach Hause und hatte unter heftigem Urindrang zu leiden. Er bemerkte, dass der Urin ganz blutig gefärbt war. Dieser Anfall ging schnell vorüber, der Urin wurde wieder klar, auch die Schmerzen, die während des Anfalls im Leib und kurz nach dem Urinlassen in der Harnröhre sich einstellten, waren wieder abgeklungen. Pat. ist verheirathet. Seine Frau ist gesund, hat zwei gesunde Kinder geboren und keine Fehlgeburt gethan. Pat. kann sich nicht erinnern, je geschlechtskrank gewesen zu sein.

Status praesens: $1,78 \mathrm{~cm}$ grosser, $57,6 \mathrm{~kg}$ schwerer Mann, mittelkräftig gebaut, gut genährt, liein Fieber, leichter leterus der Skleren, auffallend an Intensität wechselnde Anämie. Hals und Rachenorgane ohne lirankhaften Befund; speciell keine Veränderung der Mundschleimhaut. Lungen gesund, Herzgrenzen orthodiagraphisch: Medianabstand rechts 5,5, links 8,5. Action regulär, äqual. Töne rein. Puls regelmässig. Bintdruck: 118 syst., 50 diast. (Riva-Rocci). Hämoglobin 90 pCt. nach Sahli. Abdomen nicht druckempfindlich.

Probefrühstück: Gesammtmenge 80, feste Bestandtheile 25, Gesammtacidität 40, keine freie Salzsäure. Pepsin und Lab positiv. Im Stuhl nach fleischfreier Diät nie Blut nachgewiesen.

Lumbalpunction: Nonne- und Apelt'sche Globulinreaction negativ, absolut klare Flüssigkeit. Nieren nicht palpabel. Milzpol eben unter dem Rippenbogen fühl- 
bar. Leber nicht vergrössert. Im Urin Spuren von Albumen. Im Sediment einzelne granulirte Cylinder. Keine rothen Blutkörperchen.

Blutbefund: 4320000 rothe und 10000 weisse; davon 77 pCt. polynucleäre, 2,5 pCt. eosinophile, 0,5 pCt. Mastzellen, $10 \mathrm{pCt}$. grosse und $10 \mathrm{pCt}$. kleine Lymphocyten. Wassermann-Luesreaction +++ positiv, Liquor Wassermann-Luesreaction negativ. Serologische Blutuntersuchungen am 10. XI., 22. XI., 24. XI., 29. XI, 4. XII., 7. XII., 12. XII., 21. XII., 23. XIl., 31. XII., 6. I., 9. I., 15. I., 27. I., 14. III.

Bei allen Blutuntersuchungen dieses anämischen Kranken zeigten sich ganz analog dem erstgeschilderten Falle das Vorhandensein eines Hämolysins, das sich aus zwei Componenten, einem thermostabilen und einem thermolabilen zusammensetzte.

Die Versuche wurden so angestellt, dass zu einer 5 proc. Aufschwemmung fremder Menschenblutkörper fallende Mengen von activem Serum zugesetzt wurden. Mit 0,85proc. Kochsalzlösung auf das gleiche Volumen gebracht, zuerst $1 / 2$ Stunde bei $0^{\circ}$ gehalten, dann bei $37^{\circ}$ bebrütet.

\begin{tabular}{|c|c|c|c|c|c|c|}
\hline 2. B. 0. T. & 1 & 2 & 3 & 4 & 5 & 6 \\
\hline Parox. haem. & 1,0 & 0,8 & 0,6 & 0,4 & 0,2 & 0,1 \\
\hline p. normal. & 1,0 & 1,0 & 1,0 & 1,0 & 1,0 & 1,0 \\
\hline sung & 0,5 & 0,7 & 0,9 & 1,1 & 1,3 & 1,4 \\
\hline $30 \mathrm{Min}$. bei $0^{0}$ & 0 & 0 & 0 & 0 & 0 & 0 \\
\hline & & & & $\begin{array}{l}++ \\
++\end{array}$ & + & $\begin{array}{l}+? \\
+?\end{array}$ \\
\hline
\end{tabular}

Versuche über den Zusammenhang zwischen den Hemmungskörpern und dem nachgewiesenen Amboceptor führten nicht zu einem eindeutigen Resultat. Interessant war ein Versuch, in dem der nachgewiesene Kälteamboceptor zusammen mit dem eigenen Complement und den eigenen Blutkörpern als hämolytischem System fungirend bei Zusatz eines 1:7 verdünnten alkoholischen Luesleberextracts, als Antigen-Complementablenkung zeigten (s. Tabelle).

\begin{tabular}{|c|c|c|c|c|c|}
\hline Blutkörp. Tantan & 1,0 & 1,0 & 1,0 & 1,0 & 1,0 \\
\hline Alk. Lu. Le. Ex. $1: 7$ & 1,0 & 0,5 & 0,2 & 0,1 & \\
\hline Serum Tantau activ & 0,5 & 0,5 & 0,5 & 0,5 & 0,5 \\
\hline $\mathrm{NaCllösung} 0,85 \mathrm{pCt}$. & 一 & 0,5 & 0,8 & 0,9 & 1,0 \\
\hline Nach 20 Min. bei $0^{0}$ & 0 & 0 & 0 & 0 & 0 \\
\hline Nach 15 Min. bei $37^{0}$ & 0 & 0 & 0 & 0 & 0 \\
\hline Nach 7 Stunden. & 0 & 0 & 0 ? & & 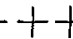 \\
\hline
\end{tabular}

Durch Vorbehandlung des Serums mit dem genannten Antigen in der Wärme eine spätere Sensibilisirung der rothen Blutkörper aus dem Serumextractgemisch in der Kälte zu verhindern, was bei Identität von Hemmungskörpern und Kälteamboceptor hätte der Fall sein können, ist nicht gelungen.

Um nun weitere serologische Analogien zwischen dem Verhalteu unseres oben beschriebenen Falles, den man als latenten Hämolytiker bezeichnen kann, mit dem Verhalten des Serums bei typischer paroxysmaler Hämoglobinurie beizubringen, wurde festgestellt, welche Abkühlung zur Fixation des Amboceptors an die Blutkörper genügte. Es wurden verschiedene Blutproben mit gleichen Serummengen je $1 / 2$ Stunde bei 
verschiedenen Temperaturen belassen und dann bei $37^{\circ}$ bebrütet. Ganz wie bei den typischen Hämoglobinurikerseren zeigte es sich, dass bei der stärksten Abkühlung $\left(0^{\circ}\right)$ die intensivste Hämolyse erzielt wurde:

Grad der primären Abkühlung des Blutkörper-Serumgemisches . . . . . . . . . . . • . 5 proc. Aufschwemmung von Hämoglobinurikerblutkörpern, je $1 \mathrm{cem}$. . . . . . . . . . . . .

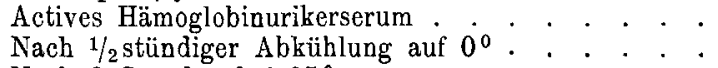
Nach 2 Stunden bei $37^{\circ}$

\begin{tabular}{|c|c|c|c}
\hline $0^{0}$ & $5^{0}$ & $8^{0}$ & $17^{0}$ \\
& & & \\
1,0 & 1,0 & 1,0 & 1,0 \\
0,3 & 0,3 & 0,3 & 03 \\
0 & 0 & 0 & 0 \\
+++ & +++ & + & 0
\end{tabular}

Als wesentliche Stütze für die Anschauungen, dass die Abkühlung des Körpers oder einzelner Theile für die Pathogenese des hämoglobinurischen Anfalles von Bedeutung sei, gilt der Umstand, dass man dem betreffenden Patienten durch kalte Fussbäder experimentell einen Anfall auslösen kann. Am 15. 1. wurde, nachdem ein Abkühlungsversuch am 18. 11. ergebnislos verlaufen war, ein zweiter solcher Versuch angestellt.

1. Blutentnahme 11 Uhr 20 Min. Vorm. Fussbad $6^{\circ}$. Dauer 11 Uhr 25 Min. - 11 Uhr 37 Min.

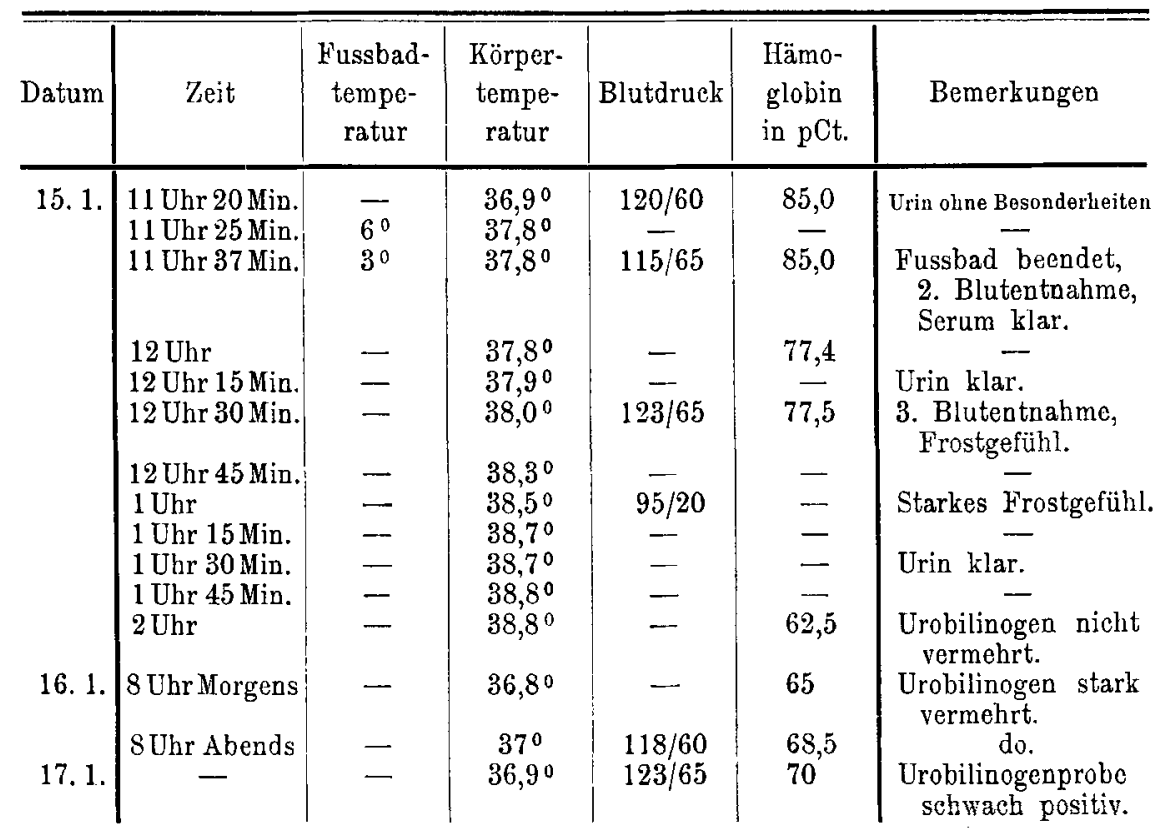

Es zeigte sich, dass bei den mit verschiedenen Blutproben $(1,2,3)$ angestellten hämolytischen Versuchen sich der Complementtiter nicht veränderte. Eine intravasculäre Hämolyse ist nicht manifest geworden, denn das Serum war stets bernsteingelb und nicht hämoglobinhaltig. Das ist um so aufallender, als eine deutlich messbare Abnahme des Hämoglobingehalts der Volumeinheit Blut mit auffälliger Anämie festgestellt werden konnte. Weiter warde nach dem Fussbad wie bei den typischen Hämoglobinurikern eine Temperatursteigerung und ein überaus starkes Frostgefühl, welches noch lange nach dem Versuch anhielt, deutlich bemerkbar. Wir 
konnten gesetzmässige Blutdruckveränderungen, wie sie Meyer und Emmerich bei ihren Versuchen beobachteten, nicht finden. Die Blutdrucksenkung auf $95 / 20$, die wir während des Versuchs feststellten, bringen wir nicht in directen Zusammenhang mit der Abkühlung, da wir auch sonst beträchtliche Schwankungen des Blutdruckes bei den Patienten beobachten konnten. Der starke, vor dem Versuch nicht nachweisbare Urobilinogengehalt des Harnes, der sich bis zum 16. Abends nachweisen liess und in deutlicher Abhängigkeit zu der vorhergehenden Abkühlung stand, deutet wohl auf einen durch die Abkühlung ausgelösten stärkeren Blutzerfall. Auch wurde der Milztumor unzweifelhaft grösser, als in den Vortagen, was in gleichem Sinne spräche. Die subicterische Verfärbung der Skleren, die bei dem Patienten dauernd bestand, schien deutlicher ausgesprochen.

Besonders bemerkenswerth erschien uns die Beobachtung einer mässigen Hämoptoe am Morgen nach dem Versuche. Es wurden etwa $30 \mathrm{ccm}$ frisch rothen Blutes ohne vorhergehenden Husten entleert. An den Jungen konnten dabei weder vorher noch später mit keinem klinischen Hilfsmittel Veränderungen festgestellt werden. Im Anschluss an diese Beobachtungen sei gleich mitgetheilt, dass der Patient, nachdem er die Arbeit wieder aufgenommen hatte, eine zweite, weit heftigere Hämoptoe bekam, für die auch keine Erklärung in den luungen gefunden wurde. Diese profusen Lungenblutungen muss man per exclusionem in einen causalen Zusammenhang mit dem Auftreten der nachgewiesenen Hämolysine bringen. Ebenso den sicher ohne Blutung einhergehenden acuten Hämoglobinsturz mit Urobilinurie am 17. 11. (cf. Hämoglobincurve).

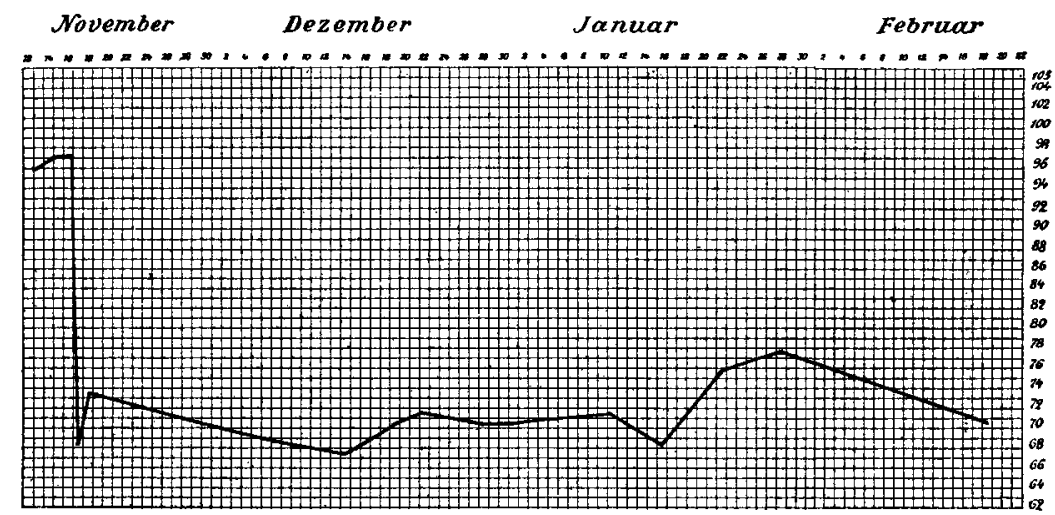

Die bei unseren Patienten sich wirksam zeigenden Hämolysine sind aber anderer Natur als die zuweilen im Serum von Lungenkranken (Tuberculösen) auffindbaren, wie wir unten sehen werden. Bald nach dieser hämolytischen Lungenblutung, deren makroskopisches Aussehen durch eine eigenthümliche lackfarbige Beschaffenheit auffiel, war eine deutliche Anschwellung der Leber und Milz nachweisbar, gleichzeitig mit dem starken Hervortreten der Urobilinogenausscheidung im Harn. Dabei traten im Urin geringe Mengen Eiweiss auf (1/4 pM. Essbach), Blut und Cylinder wurden nicht gefunden. Diese eigenthümlichen Hämoptoen 
wiederholten sich am 22., 23., 24. Februar und 20. März (mit Temperaturen bis zu $40^{\circ}$,) um dann ganz zu sistiren. Eine Gewichtsabnahme ist vom 6. 11. bis 17. 3. nicht aufgetreten. Das serologische Verhalten des Blutes hat sich während der ganzen Dauer der Beobachtung wenig oder garnicht geändert, nur in der Intensität der hämolytischen Kraft des Serums waren geringe Schwankungen zu constatiren, die aber nicht hoch anzuschlagen sind, da Blutkörper verschiedener Menschen für die Versuche verwendet wurden, und es sich zeigte, dass erhebliche Resistenzunterschiede zwischen den rothen Blutkörpern gegenüber demselben Hämolysin normalerweise existiren. Im Uebrigen konnte man alle die Eigenschaften, die die Blutkörperchen und das Serum von Hämoglobinurikern in vitro zeigen, auch bei diesem Patienten na hehweisen (Dissociirbarkeit der Blutkörper-Amboceptorverbindung, Inactivirbarkeit durch Erwärmen, Completirbarkeit durch artgleiches und artfremdes Serum [Meerschweinchen]). Es wird darauf verzichtet, die einzelnen Versuchsprotokolle hier in extenso wiederzugeben. Nur ein Versuch sei erwähnt, der sich mit der Frage befasst, ob der bei dem ersten Hämoglobinuriker nachgewiesene Kälteamboceptor mit dem in dem letzterwähnten Falle gefundenen sich identificiren lässt: Durch wiederholte Injectionen des Serums rom Fall T. (latenter Hämolytiker) wurde ein Kaninchen von $3 \mathrm{~kg}$ gegen das injicirte Serum immunisirt. Nun wurden dem Kaninchen nach Verlauf von mehreren Wochen einige Cubikcentimeter Blut entnommen und auf seine hemmende Kraft gegenüber dem Hämolysin Hess (Fall von paroxysmaler Hämoglobinurie) und dem Hämolysin T. geprüft. Es zeigte sich, dass eine antihämolytische Componente gegenüber dem Hämolysin, das zur Immunisation verwandt wurde, deutlicb nachweisbar war, während bei der gleichen Versuchsanordnung die hemmende Kraft gegenüber dem Serum des ersten Falles (Par. Hämoglobinurie) sich nicht zeigen liess. Um zu beweisen, dass das Ausbleiben der Hämolyse nicht einfach zu erklären sei durch eine Absorption des Complements an das naturgemäss entstehende Präcipitat, wurde die Flüssigkeit abcentrifugirt und dieselbe auf ihren Complementgehalt gegenüber einem hämolytischen System (Hammelblut, Kaninchenserum) geprüft, wobei sich die volle Wirksamkeit des in dem Abgusse enthaltenen Complements herausstellte. Es ist somit in diesem Falle die Erzeugung eines specifischen Antilysins geglückt, was für die Erforschung der Natur der bei verschiedenen Hämoglobinurikern entstehenden Hämolysine von Bedeutung werden kann.

Was nun die klinische Deutung dieses zweiten Falles betrifft, so muss man ihn als einen "latenten Hämolytiker" bezeichnen. - Ob die Krankheit mit der von Hunter beschriebenen Form von Anämie wesensverwandt oder identisch ist, Jassen wir vorerst dahingestellt. Jedenfalls spielen auch in seinen Fällen hämolytische Vorgänge eine bedeutsame Rolle (Hunter Severest Anaemias etc. London 1909). - Will man den anamnestisch erwähnten Anfall, der mit Entleerung eines dunklen Urins im Anschluss an eine Contusion der Nierengegend einherging, als hämoglobinurischen auffassen, so hätte das Krankheitsbild eine noch nähere Bezichung zur paroxysmalen Hämoglobinnrie. Der negative $\Lambda$ us- 
fall der Abkühlungsversuche sowie das Ausbleiben der Anfälle nach Erkältungstraumen spricht aber nicht gerade in diesem Sinne. Wir sind vielmehr der Ansicht, dass zwar bei den Patienten hämolytische Anfälle auftreten, die eine ähnliche Genese haben mögen, wie die bei der paroxysmalen Hämoglobinurie beobachteten, dass sie aber nicht zur Ausscheidung von Hämoglobin durch die Nieren zu führen brauchen. Als Erklärung für das Ausbleiben freien Hämoglobins im Harn könnte man ein besonderes promptes Arbeiten derjenigen Regulationsapparate, die freies Hämoglobin zerstören und abbauen, heranziehen. In diesem Sinne ist das Deutlichwerden des Milatumors nach der Abkühlung, das Auftreten vermehrter Mengen Urobilins im Harn zu verwerthen. Die sich der directen Beobachtung entziehenden hämolytischen Vorgänge (das Serum war zu allen Zeiten, vor und nach dem Hämoglobinsturz, stets gelb gefärbt) führen dann zu dem klinisch sichtbaren Ausdruck der hämolytischen Diathese, nämlich zur auffälligen Anämie. Besonders bemerkenswerth ist dabei das Auftreten von Lungenblutungen bei unserem lungengesunden Hämolytiker, die wohl als vicarïrende hämolytische Anfälle aufgefasst werden dürfen. Zusammenfassend muss man diesen Fall demnach als eine latente Hämolysinämie mit hämolytischen Anfällen auffassen. Diese Anfälle documentiren sich klinisch als bisher unerklärliche Hämoglobinstürze mit auffallender Anämie. Hämoglobinurie braucht dabei nicht aufzutreten, möglicherweise indess vicariirende Blutungen. Man kann also hier, was Prof. Umber auf dem Congress für innere Medicin, Wiesbaden 1911, hervorhob, von einer hämolytischen Diathese sprechen.

Es fragt sich, ob das Bestehen einer derartigen "hämolytischen Diathese" für unaufgeklärte Fälle von Anämie häufiger nachzuweisen ist. Es wurden daher, obwohl uns die Ergebnisse der Arbeit von Donath und Landsteiner (10) über Untersuchungen von Seren der verschiedensten Erkrankungen nach der Kälte-Wärmemethode bekannt waren, besonders mit Rücksicht auf das fast constante Auftreten einer stark positiven Wassermann'schen Reaction bei Fällen von paroxysmaler Hämoglobinurie, in denen klinisch alle Anzeichen einer überstandenen oder bestehenden Lues fehlen, 182 Fälle mit positiver Wassermann-Luesreaction mit der Donath-Landsteiner'schen Versuchsanordnung geprüft. Unter Ausscheidung der Sera von Paralytikern, die nach der citirten Arbeit von Donath und Landsteiner in einem gewissen Procentsatz der Fälle einen Kälteamboceptor zeigen, fanden wir ausser den beiden angeführten nur bei einem weiteren Fall ein Serum, welches die charakteristischen Eigenschaften des Hämoglobinurikerserums aufwies. Auch in diesem Falle fehlten klinische Zeichen überstandener Lues. Anamnestisch wurde eine Infection nicht eruirt.

Es handelt sich um ein 20 Jahre altes anämisches ( $64 \mathrm{pCt}$. Hämoglobin nach Sabli) Mädchen (Büttje), die spontan erzählt, dass ein jüngerer Bruder von ihr anfallsweise einen dunklen Urin entleerte. (Dieser Fall war der Untersuchung leider nicht zugänglich.) Das Serum des Mädchens löste, wie nachstehende Tabelle zejgt, die Blutkörper anderer Menschen nach vorheriger Abkühlung auf $0^{0}$ prompt auf, während ihre eigenen Blutkörper von der Lyse verschont blieben; durch $1 / 2$ stündiges Erwärmen auf $50^{\circ}$ wurde der wirksame Körper bereits zerstört (cf. Tabelle). 
Kälteamboceptor als Isolysin.

A. Die Blutkörperserumgemische werden sofort bei $37^{\circ}$ bebrütet.

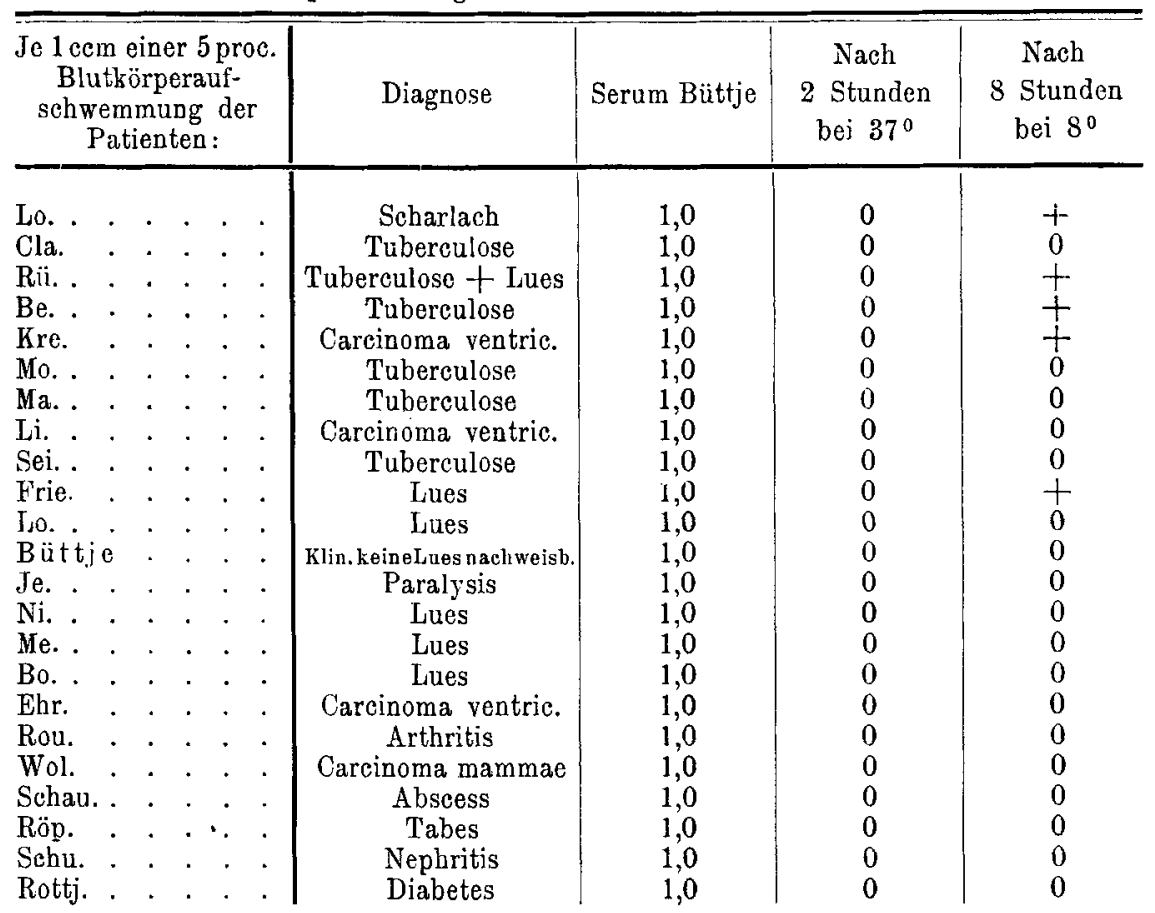

B. Die Blutkörpergemische werden a ach halbstündigem Verweilen bei $0^{0}$ bei $37^{\circ}$ bebrütet.

\begin{tabular}{|c|c|c|c|c|c|}
\hline $\begin{array}{c}\text { Je } 1 \text { cem einer } 5 \text { proc. } \\
\text { Blutkörperauf- } \\
\text { schwemmung der } \\
\text { Patienten: }\end{array}$ & Diagnose & $\begin{array}{l}\text { Serum } \\
\text { Büttje }\end{array}$ & $\begin{array}{c}\text { Nach } \\
1 / 2 \text { Stunde } \\
\text { bei } 0^{0}\end{array}$ & $\begin{array}{c}\text { Nach } \\
\text { 2 Stunden } \\
\text { bei } 37^{\circ}\end{array}$ & $\begin{array}{c}\text { Nach } \\
12 \text { Stunden } \\
\text { bei } 8^{\circ}\end{array}$ \\
\hline 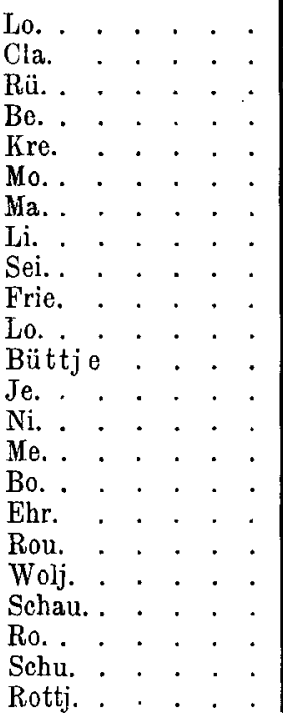 & $\begin{array}{c}\text { Scharlach } \\
\text { Tuberculose } \\
\text { Tuberculose + Lues } \\
\text { Tuberculose } \\
\text { Carcinoma ventric. } \\
\text { Tuberculose } \\
\text { Tuberculose } \\
\text { Carcinoma ventric. } \\
\text { Tuberculose } \\
\text { Lues } \\
\text { Lues } \\
\text { Klin. keineLues nachweisb. } \\
\text { Paralysis } \\
\text { Lues } \\
\text { Lues } \\
\text { Lues } \\
\text { Carcinoma ventric. } \\
\text { Artbritis } \\
\text { Carcinoma mammae } \\
\text { Abscess } \\
\text { Tabes } \\
\text { Nephritis } \\
\text { Diabetes }\end{array}$ & $\begin{array}{l}1,0 \\
1,0 \\
1,0 \\
1,0 \\
1,0 \\
1,0 \\
1,0 \\
1,0 \\
1,0 \\
1,0 \\
1,0 \\
1,0 \\
1,0 \\
1,0 \\
1,0 \\
1,0 \\
1,0 \\
1,0 \\
1,0 \\
1,0 \\
1,0 \\
1,0 \\
1,0\end{array}$ & $\begin{array}{l}0 \\
0 \\
0 \\
0 \\
0 \\
0 \\
0 \\
0 \\
0 \\
0 \\
0 \\
0 \\
0 \\
0 \\
0 \\
0 \\
0 \\
0 \\
0 \\
0 \\
0 \\
0 \\
0\end{array}$ & $\begin{array}{c}++ \\
+++ \\
++ \\
+++ \\
+++ \\
+? \\
++ \\
+?\end{array}$ & $\begin{array}{c}++ \\
+\end{array}$ \\
\hline
\end{tabular}


In- nnd Reactivirungsversnche mit Serum Büttje.

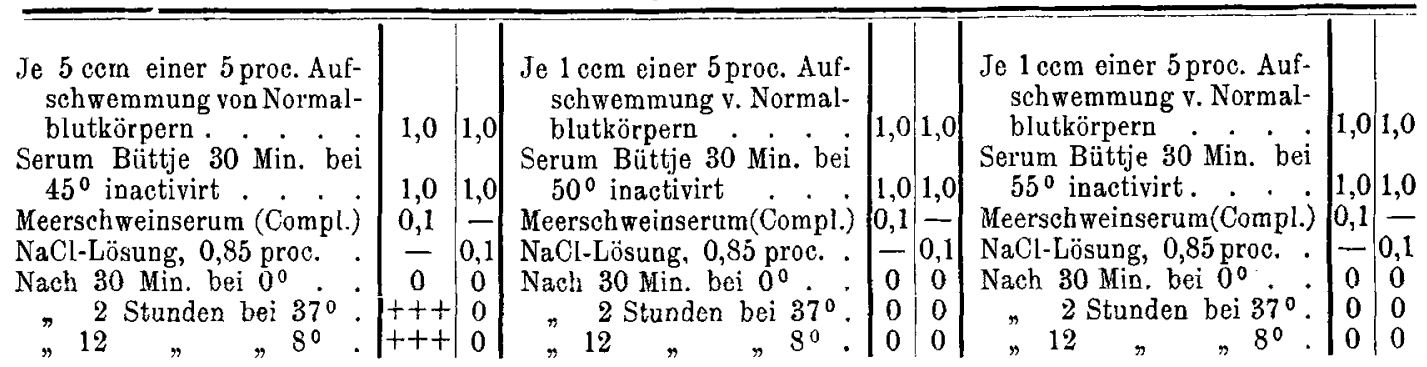

In Uebereinstimmung mit dieser Resistenz der Blutkörper der Patientin gegen ihr eigenes Serum konnte bei ihr selbst durch 20 Minuten lange Abkühlung der Füsse und Unterschenkel bei $0^{0}$ weder eine Hämoglobinurie noch Temperaturerhöhung erzeugt werden. Auch ein vermehrtes Auftreten von Urobilinogen im Harn wie in zweiten Falle konnte nicht beobachtet werden. Es ist denkbar, dass zu einer früheren Zeit hämolytische Vorgänge in ihrem Körper sich abgespielt haben, die dann schliesslich zu einer Immunisation der neugebildeten Erythrocyten gegen den nachweisbaren Kältoamboceptor führten. Während bei den typischen Hämoglobinurikern eine gewisse Abkühlung des Blutkörper-Serumgemisches Vorbedingung ist für den positiven Ausfall des hämolytischen Versuches, waren in dem eben erwähnten Falle bereits Spuren von Hämolyse ohne vorherige Abkühlung nachweisbar. Es zeigte sich ferner, dass die einmal nachgewiesenen Eigenschaften bei mehrfacher Wiederholung der Versuche an verschiedenen Tagen (nach stets erneuerter Blutentnahme) constante waren; an einem Fall gelang es uns aber doch, zu zeigen, dass auch ein in dieser Beziehung abweichendes Verhalten vorkommt. Es handelt sich um einen Mann mit Tabes incipiens. Hier war bei der ersten Untersuchung ein nur gegen fremde Blutkörper wirksamer Kälteamboceptor deutlich nachweisbar, während die Blutkörper-Serumgemische, die sofort bei $37^{\circ}$ bebrütet wurden, keine Hämolyse zeigten. Bei einer Nachuntersuchung, die acht Tage später angestellt wurde, trat sowohl im Abkühlungsversuch, als in der Controle, die sofort der Brutschranktemperatur ausgesetzt wurde, eine deutliche Hämolyse ein.

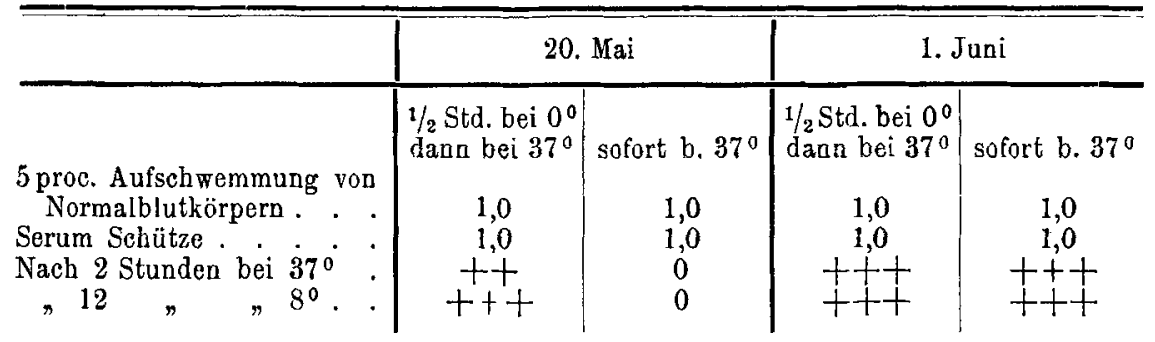

Ob die Eigenschalt sowohl nach vorheriger Abkühlung, als auch bei sofortiger Wärmebehandlung hämolytisch zu wirken, ein und denselben oder verschiedenen Körpern in diesem Fall zukamen, konnte mit Sicherheit nicht entschieden werden. Durch diesen Befund aufmerksam gemacht, muss man sich aber doch die Frage vorlegen, ob der bei der 
paroxysmalen Hämoglobinurie nachgewiesene hämolytische Körper jedes Mal eine weit unter Körpertemperatur gehende Abkühlung zum Wirksamwerden bedarf oder ob auch hier ein wechselndes Verhalten statthaben kann.

Hämolysine bei verschiedenen anämisirenden Krankheitsgruppen, Resistenz der rothen Blutkörper Krebskranker gegen Hämolysine; Beziehungen zwischen Anftreten von Hämolysinen im Serum und vermehrtem Auftreten voll colloidalem Stickstoff im Serum und Harn Krebskranker.

Unsere hämolytischen Studien wurden nicht beschränkt auf das Auffinden von Körpern, die den bei den Donath-Landsteiner'schen Versuchen nachgewiesenen identisch waren, sondern erstreckten sich überhaupt auf Stoffe, die im menschlichen Blutserum vorhanden, gegen menschliche Blutkörper bei irgend welchen Bedingungen sich wirksam zeigen. Seit den Untersuchungen von Faust und Tallquist (23) über die Bothriocephalusanämie haben sich vor allem Grafe und Römer $(6,7)$ mit der Frage beschäftigt, ob man auch bei anderen Formen der perniciösen Anämie einen hämolytischen Körper auffinden könne. Sie fanden, dass das Extract der Darmschleimhaut von chronsich Darmkranken hämoJytische Körper enthaiten könne. Da jedoch nachgewiesenermaassen freie Fettsäuren eine hohe hämolytische Kraft besitzen, und dieselben in Spuren in jedem Koth nachweisbar sind, so ist eine quantitative Auswerthung der hämolytischen Factoren des Kothes nothwendig, wenn man Unterschiede zwischen Normalen und Kranken feststellen will; dabei stösst man naturgemäss auf Schwierigkeiten, da man sicher noch nicht alle hämolytisch wirksamen Substanzen der Faeces kennt (eigene Versuche aus dem Simmond'schen Institut in Hamburg St. Georg zeigten mir das). Aussichtsreicher in diagnostischer Beziehung schien daher ein anderer Weg, nämlich hämolytische Substanzen im Serum aufzusuchen.

Bei dem Fahnden nach solchen Körpern fanden wir bald Sera, die eine hohe hämolytische Kraft gegen Menschenblutkörperchen auch ohne vorherige Abkühlung zeigten. Zugleich fiel auf, dass nicht die Blutkörper aller untersuchten Fälle gleichmässig gelöst wurden. Es ergeben sich aus diesen Beobachtungen mehrere Fragestellungen.

1. Wie vertheilen sich die Isolysine auf Gesunde und Kranke?

2. Wie vertheilen sich die Hämolysine auf die verschiedenen Krankheitsgruppen.

3. Iuässt sich in dem Verhalten der rothen Blutkörper gegenüber den erwähnten Hämolysinen eine Gesetzmässigkeit feststellen.

Um an grossen Reihen von Serum und Blutkörperchen diese Frage prüfen zu können, stellt sich folgendes Verfahren als zweckmässig heraus:

Es wurden einer Reihe von 12-24 an verschiedenen Krankbeiten leidenden und gesunden Menschen am gleichen 'Tage durch Venenpunction etwa $30 \mathrm{ccm}$ Blut entzogen, das in Centrifugengläsern aufgefangen, sofort durch Rühren mit einem Glasstab defibrinirt wurde. Nach dem Abcentrifugiren des Serums wurden die Blutkörperchen 3 mal mit 0,85 proc. Kochsalzlösung gewaschen und 5 proc. Aufschwemmungen davon hergestellt. Bei diesen Aufschwemmungen wurde stets die Hämoglobin- 
zahl ber ücksichtigt aus folgendem Grund. Da ganz completeHämolysen bei stärkstwirksamen unverdünnten benutzten Seren eine Seltenheit sind, ist man bei vergleichenden Untersuchungen auf die Berücksichtigung des Färbetiters der über den restirenden Blutkörperchen oder Blutkörperchentrümmern stehenden Flüssigkeit angewiesen. Die Färbeintensität ist bei sonst gleichen Verbältnissen abhängig 1. von der hämoIytischen Kraft des zugesetzten Serums, 2. von der Menge des zur Verfügung stehenden Hämoglobins, 3. von der Zahl in dor Aufsohwemmung vorhandener Blutkörperchen. Die erste Grösse ist die gesuchte, die zweite und dritte können gemessen werden. Im Allgemeinen wurde nur die zweite gemessen, da es sich zeigte, dass das für die vorliegende Untersuchung vollkommen ausreichte. Eine 5 proc. Blutkörperaufschwemmung wurde von einem Blute mit $50 \mathrm{pCt}$. Hämoglobin demnach so hergestellt, dass das Volumen der 3 mal mit Kochsalz gewaschenen Blutkörper zunächst dem Ausgangsvolumen des frisch entnommenen Blutes gleich gemacht wurde. Von dieser Aufschwemmung wurden $2 \mathrm{ccm}$ mit Kochsalz auf 20 verdünnt. Je $1 \mathrm{ccm}$ einer so hergestellten Aufschwemmung verschiedener Blutkörper wurden nun mit je $1 \mathrm{ccm}$ sicher hämolytischen activen Serums versetzt. (Meist wurde dazu Serum von Kranken mit Carcinoma vontriculi verwandt.) Die Gemische durchgeschüttelt und das Resultat nach einstündigem Verweilen bei $37^{\circ}$ zum ersten Male, dann nach weiteren 12 Stunden Verweilen im Eisschrank zum zweiten Male abgelesen. Das Resultat in üblicher Weise anfgezeichnet mit,,,++++++ 0 , wobei +++ eine tiefrothe und + eine schwachrothe, aber deutliche Färbung der über den Blutkörpern stehenden Flüssigkeit bedeutet. Die Agglutination, die in ihrem Auftreten oder Ausbleiben auch gewisse Gesetzmässigkeiten zeigte (cf. von Dungern und Hirschfeld, Ueber gruppenspecifische Structuren des Blutes 11), wird in den Protokollen nicht mit angegeben. In dieser ersten Reihe wurden die gegenüber Hämolysinen empfindlichsten Blutkörper des betreffenden Untersuchungstages ermittelt. Diese für Hämolysinwirkung empfänglichen Blutkörper wurden in weiteren Reihen mit je $1 \mathrm{ccm}$ der zu untersuchenden Sera versetzt. Alie sich als hämolytisch zeigenden Sera wurden dann bei $45^{\circ}, 50^{\circ}, 55^{01}$ ) inactivirt, dann reactivirt (durch Meerschwein-oder Menschenserum). In einer dritten Reihe wurden ferner je $1 \mathrm{ccm}$ jedes hämolytischen Serums mit je $1 \mathrm{ccm}$ aller zur Verfügung stehenden Blutkörperaufschwemmungen auf ihr Verhalten gegenüber Saponin, Oelsäure und Natriumoleat geprüft. In dieser Weise untersuchten wir 500 Reihen mit je 12-24 Einzeluntersuchungen.

Die nach dem angegebenen Verfahren angestellten Untersuchungen lehrten nun bald erkennen, dass bei gewissen Krankheitsgruppen das Auftreten hämolytischer Körper im Serum anscheinend ein besonders häufiges ist. Nicht einbegriffen in diese Untersuchungen sind Fälle mit Bakteriämie. Vor allen fand sich, dass in einem hohen Procentsatz der Fälle das Serum von Carcinomkranken ${ }^{2}$ ) hämolytische Eigenschaften gegen Menschenblutkörper zeigte. Diese Beobachtung ist nicht neu. Seit Kelling's Untersuchungen, der mehrere diagnostische Methoden auf den Befund von Hämolysinen bei Carcinomkranken aufbaute, sind verschiedene Nachprüfungen angestellt worden, die theils eine klinische Brauchbarkeit derselben behaupten, theils sich ablehnend verhalten. Die zu-

1) Es zeigte sich, dass einige stark wirksame Sera schon bei Temperaturen unter $50^{\circ}$ ihre Wirksamkeit verloren (cf. S. 201 oben).

2) Grafo und Graham (Münch. med. Wochenschr. No. 43. 1911) fanden bei Gesunden und Kranken gleich oft Isolysine. Die Differenz zwischen ihren und den Resultaten anderer Autoren erklären sie u. a. damit, dass früher die Sera nur gegen 3 oder 4 Blutkörpersorten untersucht wurden. Für uns trifft dieser Einwand nicht zu, da unsere Sera stets gegen 12-24 verschiedene Blutkörpersorten geprüft wurden. 
nächst wichtigere Frage, ob das Auftreten solcher Körper mit dem Wachsthum der malignen Neubildung in biologischer Wechselbeziehung steht, oder ob es sich um hämolytische Wirkungen von Gewebszerfallproducten handelt, die aber auch bei anderen Krankheitsprocessen auftreten können, wird nur nebenbei erörtert. Eine weitere Möglichkeit, dass nämlich die bei Carcinomkranken nachgewiesenen Hämolysine Reactionsproducte gegen zerfallene Blutkörper darstellen (also eine Autoimmunisirung) wird von Richartz (21) als wahrscheinlich hingestellt. Ohne nun unsere Protokolle hier in extenso wiederzugeben, beschränke ich mich darauf, in tabellarischer Form einige Resultate aus denselben zusammenzustellen. Tabelle I (s. Anhang) zeigt, dass unter den verschiedenen Krankheitsgruppen Hämolysine, wie bereits bemerkt wurde, bei Krebskranken besonders häufig auftreten, doch ist die Zahl der Fälle nicht gross genug, um gesetzmässige Zahlenverhältnisse zu gewinnen. Richartz (21) fand an einem viel grösseren Material bei Carcinomatösen und Tuberculösen in mindestens $48-52$ pCt. lösende Stoffe für normale Erythrocyten anderer Personen. Das Auftreten von Hämolysinen bei Syphilitikern ist nicht so bekannt. Es ist deshalb bemerkenswerth, weil Tschernogubou, Noguchi und von Dungern ein gegenüber Menschenblutkörpern wirksames hämolytisches System bei der Wassermann'schen Reaction empfohlen haben. Unter den hochgradigen Anämien (dritte Rubrik) finden wir, was besonders hervorgehoben sei, drei Mal hämolytisch sehr wirksame Körper im Serum, die mit der vorhandenen Anämie sehr wohl in Beziehung stehen können. $\mathrm{Ob}$ hier jedoch die Anämie Folge des Bestehens eines hämolytischen Körpers ist, liess sich bis jetzt nicht entscheiden. In allen drei Fällen konnte nach den klinischen Befunden die Diagnose Tumor so gut wie ausgeschlossen werden. (Parasiten oder Parasiteneier wurden nicht gefunden.)

Die vierte Rubrik umfasst positive Hämolysinbefunde mit verschiedenen Krankheiten, bei weiterem Studium der Frage und bei grösserem Material wird man hier noch mehrere unter sich verwandte Gruppen aufstellen können. Als diagnostisch bemerkenswerth sei hervorgehoben, dass wir in Fällen von sehr festem, altem, abgekapseltem appendicitischem Abscess, wo die Differentialdiagnose zwischen Abscess und malignem Coecaltumor offen bleiben musste, eine positive Hämolysinreaction fanden. (Das Blut war in beiden Fällen steril.) Eine auf den Hämolysinbefund gestützte Diagnose wäre also irregeleitet worden. Ferner zeigten sich bei Scharlachkranken im Stadium des Exanthems bisweilen Isohämolysine. Da wir auch bei Gesunden, wenn auch schwache, Isolysine beobachteten, schien uns anfangs eine absolute Regellosigkeit in dem Auftreten dieser Körper zu herrschen. Wir hofften aber unter Berücksichtigung der Stärke der hämolytischen Kraft zu neuen Gesichtspunkten zu kommen.

Es sei nun in einer zweiten Tabelle (s. Tabelle II) zunächst gezeigt, wie die Hämolysine bei den verschiedenen Formen des Carcinoms sich verhalten. Interessanter Weise zeigt sich, dass mit Ausnahme der Oesophaguscarcinome die intestinalen Krebse besonders gute Hämo- 
lysinbildner darstellen. Unter diesen wieder scheinen die Magencarcinome die wirksamsten zu sein. Von den 21 untersuchten Fällen von Magencarcinom sind $13=62$ pCt. stark hämolysirend. Dieser Befund, zusammengehalten mit der Thatsache, dass, so weit untersucht, die hämolytisch wirksamsten Sera den hämoglobinärmsten Patienten zugehören, spricht gegen ein blos zufälliges Zusammentreffen von Isolysinen und Carcinoma ventriculi. $O b$ die Anämic in Beziehung zu bringen ist zu dem Vorhandensein hämolytisch wirksamer Substanzen, lassen wir dahingestellt. Letzteres erscheint zwar deshalb wenig wahrscheinlich, weil es uns nicht in einem einzigen diagnosticirten Carcinomfall gelang, ein Autohämolysin nachzuweisen. Im Gegentheil ergab sich das unerwartete Verhalten, dass Carcinomblutkörper nicht blos gegen das eigene, sondern auch sehr häufig gegen fremde hämolytisch wirksame Carcinomsera immun (resistent) sind. (Tabelle III.) Jedoch wissen wir seit den Untersuchungen von Schminke und Flury (31) am chronisch mit 0elsäure vergifteten Hund, dass dieses Gift anfangs eine stark anämisirende Wirkung ausübt. Späterhin aber zeigen die Blutkörperchen des vorbehandelten Thieres eine erhöhte Resistenz gegen diesen Körper. Nach den Befunden von vermehrten Mengen von Oelsäure im Mageninhalt der an Carcinoma ventriculi leidenden Patienten (Grafe und Römer) lag es nahe, für die Erklärung der Anämie der Krebskranken und die erhöhte Resistenz gegen Carcinomisolysine an ähnliche Vorgänge wie die bei dem mit Oelsäure vergifteten Hund beobachteten $z a$ denken.

Schon glaubten wir, auf dem Befund der Resistenz von Carcinomblutkörpern gegen hämolytische Carcinomsera eine diagnostische Methode aufbauen zu können, da zeigte sich, dass auch Blutkörper anderer Kranker diese Resistenz besitzen, wie das Tabelle IV demonstrirt. Hier fanden wir, dass neben dem Carcinom (Stab 9) auch die Blutkörper von Luetikern (Stab 1, 2, 3 und Stab 14, 15 und 2 Fälle mit Kälteamboceptor, Stab 7 und 13) resistent sind. Wir fragten uns weiter, ob die Blutkörper, die gegen ein hämolytisches Carcinomserum Resistenz zeigen, sich auch gegenüber anderen hämolytisch wirksamen Seren so verhalten. Dass das der Fall ist, lehrt Versuch No. 144 und 145 (Tabelle III), No. 396, 397 (Tabelle VIII) und No. 360, 363, 366 (T'abelle X). Man sieht also, dass, wenn die Blutkörper einer Person gegen ein Carcinomhämolysin Resistenz zeigen, sie dieses auch gegen andere Carcinomhämolysine thun. Noch merkwürdigere Beziehungen ergeben sich aber, wenn man nicht blos hämolytisch wirksame Sera Carcinomkranker, sondern auch andere Erkrankungen in Betracht zieht. Es wurde schon eingangs angedeutet, dass ausser bei Carcinomen besonders bei Lues, Tuberculose und einigen Fällen von Scharlach Hämolysine auftreten. Tabelle IV, VIII, IX, X zeigen nun, wie die gegen Carcinomhämolysine resistenten Blutkörper auch für die Jsohämolysine anderer Provenienz unangreifbar sind. Durchweg ist hier ein Parallelgehen der Fragilität oder der Resistenz der rothen Blutkörper gegenüber allen hämolytischen Seris deutlich: 
Tabelle IV, Versuch No. 237, 242, 243.

Resistenz in Columne: 1, 2, 3, 9, 10, 11, 13, 14 .

Fragilität in Columne: $4,6,8,16,18$.

Tabelle X, Versuch No. 360, 366, 363.

Resistenz in Columne: 4, 5, 6, 8, 9, 12, 13, 17, 18, 20, 21, 22.

Fragilität in Columne: 1, 2, 7, 14, 15, 16 .

Tabelle VIII, Versuch No. 393, 396.

Resistenz in Columne: $1,2,4,5,8,9$.

Fragilität in Columne: $3,6,7,10$.

Tabelle IX, Versuch No. 304, 315, 316, 317, 318.

Resistenz in Columne: 2, 4, 6, 7, 8, 10, 13, 14.

Fragilität in Columne: 1, 3, 5, 9, 11.

Wie dieser Befund zu deuten ist, ist nicht ohne Weiteres klar. Jedenfalls spricht es für cine nahe Verwandtschaft (chemische, biochemische) der verschiedenen hämolytischen Körper unter sich. Man müsste sonst die Annahme machen, dass die Blutkörper, die mit Schutzkörpern gegen das Hämolysin der einen Art ausgerüstet sind, zugleich gegen Hämolysine ganz anderer Herkunft immun sind, was gegen alle Erfahrung spricht. Wahrscheinlich ist es, dass die beim Carcinom nachgewiesenen Hämolysinc nicht für dasselbe charakteristisch sind, sondern sich vielleicht dereinst als Lipoidstoffe entpuppen werden. Dass die Bildung aller Isolysine cin rein physiologischer Vorgang sei - eine Ansicht, die u. A. Landsteiner und Leiner (Centralbl. f. Bacter., 38, 1905) vertreten - können wir wenigstens nicht für die "CarcinomhämoJysine" gelten lassen, die oft durch ihre äusserst intensive Wirksamkeit und dann, wenn sie auch ohne Complement (cf. oben S. 208) Iösen, sofort aus der Reihe der "physiologischen Isolysine" herausfallen. In dieser Richtung wurden einige Versuche angestellt, die sich mit der Frage befassten, ob man dieselben Reihen resistenter oder nicht resistenter Blutkörper, wie sie durch hämolytische Seren gebildet wurden, auch durch Linwirkung chemisch definirter Körper erhalten kann. In den Versuchen Tabelle VIII, Tabelle $X$, Versuch No. 134, 361, 355 ist gezeigt, dass die Empfindlichkeit von verschicdenen Menschen stammender Blutkörper gegenüber hämolytisch wirksamen chemisch definirten Stoffen (Natrium oleat. resp. Oelsäure und Saponin) absolut nicht die gleiche ist, sondern in weiten Grenzen schwankt, im Gegensatz zu den bei den verschiedenen Krankheitszuständen aufgefundenen hämolytischen Serumstoffen. Ihnen gegenüber verhalten sich von verschiedenen Menschen stammende Blutkörper fast stets gleich, d. h. worden die Blutkörperchen eines Menschen von einem menschlichen hämolytisch wirksamen Serum gelöst, so werden sie in der Regel von allen solchen Seris gelöst. Dass von dieser Regel Ausnahmen vorkommen, lehrt Tabelle V; hier wurden 4 isolytische Sera gegen die Blutkörperchen von 12 verschiedenen Menschen geprüft (3 Normale, 7 Carcinome, 1 Lues, 1 pernic. Anämie). Wie dieser Befund sich mit den vorstehenden unter ein Gesetz bringen lässt, ist vorerst nicht zu sagen. Dass gewisse Regelmässigkeiten in 
dem Verhalten von Isolysinen und rothen Blutkörperchen sich gruppenweise nachweisen lassen, glauben wir hinlänglich gezeigt zu haben. Nur können wir bislang die Befunde nicht zwanglos in ein Schema einordnen ${ }^{\mathbf{1}}$ ).

Für Natriumoleat und Oelsäure konnten gleichfalls erhebliche Differenzen der Resistenz gezejgt werden, doch nie gingen diese parallel mit der Fragilität resp. Resistenz der Blutkörper durch die verschiedenen Hämolysine des menschlichen Serums. Auf diesem Wege also konnte ein äbereinstimmendes Verhalten einer Reihe von rothen Blntkörpern gegenüber Serumhämolysinen, z. B. Carcinomserum mit chemischen hämolytischen Substanzen (Oelsäure), nicht gezeigt werden. Wir haben besonders deshalb zahlreiche vergleichende Untersuchungen über das Verhalten der rothen Blutkörper gegenüber Serumbämolysinen und Natriumoleat (resp. Oelsäure) gemacht, weil nach den Untersuchungen von Grafe und Römer erhebliche Oelsäuremengen im Mageninhalt Carcinomkranker sich nachweisen lassen. (Wir haben uns davon selbst mit der von genannten Autoren vorgeschlagenen Bestimmung der Hübl'schen Jodzahl überzeugt, halten die Methode aber zu umständlich, als dass wir sie für klinische Zwecke empfehlen könnten.) Wir vermutheten, dass vielleicht vermehrte Mengen Natriumoleat resp. Oelsäure durch Rückresorption von der Magenwand aus in den Kreislauf gelangen und hier ihre hämolytische Wirksamkeit entfalten können. Da nun gerade Carcinomblutkörper nach unseren Untersuchungen von Carcinomseren im Allgemeinen nicht gelöst werden, sich also ihnen gegenüber resistent zeigen, hätte, wenn das bämolytisch wirksame Princip wirklich die Oelsäure gewesen wäre, man eine relative Resistenz der rothen Blutkörper Carcinomkranker auch der Oelsäure gegenüber erwarten dürfen. Aus den Tabellen geht hervor, dass das nicht der Fall ist. Dass diese Serumbämolysine sich, soweit untersucht, in vielen Fällen wie complexe Hämolysine verhielten, brauchte von vornherein nicht gegen die eben erwähnte Vermuthnng zu sprechen, da nach Versuchen von v. Lieberm an $n$ und Noguchi die Seifen ein den complexen Hämolysinen ähnliches Verhalten zeigen können. Gewisse Analogien zu der Seifenhämolyse bestehen auch insofern, als man unter bestimmten Bedingungen durch Zusatz von nicht hämolytischen Seris zu hämolytischen das Eintreten der Hämolyse verhindern kann. Von Li e b erm an nund N o gu chi könnten ein Gleiches beiCombination von hämolytisch wirksamen Seifenverdünnungen mit Seris zeigen.

Bei dieser Gelegenheit sei auf einige Ejgenschaften der von uns untersuchten hämolytischen Sera hingewiesen, die bislang nur als zufällige Beobachtung bewerthet werden können, da Gesetzmässigkeiten sich hier erst an grösserem Material und zahlreichen Einzeluntersuchungen ableiten lassen.

I. Von den untersuchten hämolytischen Carcinomseren konnten wir $4^{2}$ )

1) Lange nach Abschluss dieser Arbeit kam uns die Arbeit von Grafe und Graham "Untersuchungen über Isolyse" zu Gesicht (Münehener med. Wochenschr., No. 43, 1911). Diø Autoren, deren Resultate in vielen Punkten mit den unseren übereinstimmen, ordneten ihre Befunde in ein Zweigruppenschema ein (in Anlehnung an das Verfahren von v. Dungern und Hirschfeld bei den Isoagglutininen).

2) Anmerkung bei der Correctur: Die Vorsicht, die completirenden Sera auf Hemmungskörper zu untersuchen, wie Grafe und Graham (l, c.) es thaten, haben wir nicht geübt. Unsere Zahl ist deshalb zu niedrig. 
durch $1 / 2$ stündiges Erhitzen auf $56^{\circ}$ inactiviren, durch späteren $\mathrm{Zu}$ satz sowohl von $0,1 \mathrm{ccm}$ Menschen- als auch Meerschweinblut reactiviren. In anderen Fällen konnten wir aber auch bei sicherer Abwesenheit von Complement eine gute starke hämolytische Kraft des Serums demonstriren, so war z. B. ein Serum noch 3 Wochen nach Entnahme gut hämolytisch wirksam, während es andere hämolytische Systeme nicht zu completiren vermochte. In 2 Fällen verlor sofort post mortem noch körperwarm entnommenes Blut seine hämolytischen Fähigkeiten, ohne dass sich dafür eine Erklärung finden liess.

II. Combinationen hämolytisch wirksamer und unwirksamer Sera und hämolytisch wirksamer untereinander gaben verschiedene Resultate, meist aber in dem Sinne, dass bei Combination zweier hämolytisch wirksamer Sera eine Additionswirkung zu Stande kommt, während die Gegenwart unwirksamer Sera die hämolytische Kraft wirksamer Sera erheblich zu beeinträchtigen resp. aufzuheben im Stande ist (Tab.VI).

III. Bringt man das Blutkörperserumgemisch (empfindliche Blutkörper + stark wirksamem Serum) zunächst für eine halbe Stunde bei $0^{\circ}$ und sodann bei $37^{\circ}$, bleibt die hämolytische Wirkung oft aus, oder wird erheblich geschwächt (Tab. VlI $)^{1}$ ).

IV. Alkoholischer Extract aus hämolytisch wirksamen Sera zeigten in wenigen Versuchen keine höhere als die durch Alkohol allein bedingte hämolytische Wirkung.

Wenn nun auch in vorstehenden Untersuchungsreihen für die chemische Natur der im menschlichen Serum vorkommenden Hämolysine bisher Anhaltspunkte nicht gewonnen werden konnten, so ist das gleichmässige Verhalten ganzer Reihen verschiedener rother Blutkörper von verschiedenen Kranken stammenden hämolytischen Seren gegenüber festgestellt. Damit aber fällt das exceptionelle, das anfangs das Auftreten von Hämolysinen bei Carcinom zu bedeuten schien, fort. Das gerade bei den Fällen, wo die Anämie am grössten, oft auch die hämolytische Kraft des Serums die intensivste, und die Resistenz der Blutkörperchen gegenüber den eigenen und anderen Carcinombämolysinen eine absolute war (Tab. No. II), ist eine 'Thatsache, die wir gleichfalls nicht in dem Sinne deuten möchten, dass nach einem primären Blutzerfall auf autoimmunisatorischem Wege Lysine erzeugt worden seien, sondern wir glauben; dass neben anderen unwirksamen Zerfallsproducten des Carcinoms auch solche bämolytischer Natur frei werden, vielleicht unter Mitwirkung normaler Weise im Körper vorhandener Fermente. Dass intestinale Carcinome hämolytisch am wirksamsten sind, lässt sich mit dieser Annahme gut vereinen, denn erstens liegen im Intestinum die Resorptionsbedingungen am günstigsten und dann sind dort verdauende Fermente àm reichlichsten und wirksamsten vertreten.

Wir glauben nun zur Erklärung dieses Verhaltens gewisse Anhaltspunkte gefunden zu haben, aus Resultaten, die uns die Bestimmung des colloidalen Stickstoffes im Harn Krebskranker lieferte

1) Diese Thatsache warnt uns davor, alle Hemmungsvorgänge durch fremde Sera stets auf in ihnen enthaltene specifische Antiisoamboceptoren zu beziehen. 
[nach Salkowski (32)]. Wir fanden nämlich gerade für die hämolytisch wirksamsten Magencarcinome die höchsten Colloidalstickstoffzahlen im Harn (Tab. XI). Wir haben diesem Befunde die Deutung gegeben, dass höhere proteolytische Eiweissabbauproducte von der Umgebung des Carcinorms aus, ohne den Darm zu passiren, direct in den Kreislauf resorbirt werden und zum Theil in den Urin übergehen (Analogien dafür bieten die hohen Colloidalstickstoffzahlen, die Stefano Manzini im Harn von Pneumonikern im Lösungsstadium fand). Eine andere Erklärungsmöglichkeit wäre die, dass die nachgewiesenen hämolytischen Körper selbst fermentative Eigenschaften hätten, deren Wirksamwerden dann dic erwähnten Ausscheidungen theilweise parenteral abgebauten Eiweisses zur Folge hätten (eben die Polypeptide). Versuche darüber, ob dies Verhalten sich auch bei nicht krebskranken Hämolysinämikern feststellen lässt, sind im Gange.

Wir haben diesen Fragen auch biologisch näher zu kommen versucht; seitdem durch die neuere Anaphylaxieforschung wieder mit besonderem Nachdruck auf die enorme Giftigkeit höherer Eiweissspaltproducte hingewiesen wurde, schien uns der Versuch gerechtfertigt, die Sera Carcinomkranker auf eine erhöhte primäre Toxicität im Thierversuch zu prüfen. Wir gingen dabei in einer ersten Reihe von Untersuchungen so vor, dass wir Meerschweinchen actives Menschenserum in Dosen von $1-2 \mathrm{ccm}$ in die Vena jugularis injicirten. Wir konnten dabei sehr oft mit Seren, die von den verschiedensten Kranken stammten, einen acuten anaphylaktischen Tod auslösen, mit allen dafür als charakteristisch beschriebenen Symptomen. Wir haben im Ganzen in der angegebenen Weise 85 Thiere gespritzt. Davon starben in der ersten Viertelstunde 12 Thiere unter anaphylaktischen Zeichen. Von $9 \mathrm{mit}$ Carcinomseren gespritzten, hämolytischen und nicht hämolytischen, erkrankten 2 unter anaphylaktischen Erscheinungen, erholten sich aber bald wieder. Als Beispiel mögen folgende Wiedergaben aus unseren Protokollen dienen. (Prot. No. 73, 75, 85, 86).

Diagnose: Diphtherie.

\begin{tabular}{|c|c|c|c|c|c|c|c|c|c|c|}
\hline 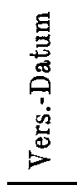 & 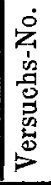 & 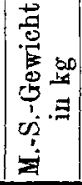 & 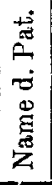 & $\stackrel{4}{\vec{\Phi}}$ & 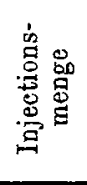 & 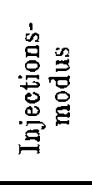 & Zeit & 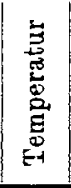 & Bemerkungen & Sectionsbefund \\
\hline 5. 4 . & 73 & 0,200 & B. & 87 & $1 \mathrm{ccm}$ & $\begin{array}{l}\text { Intra- } \\
\text { venös } \\
\text { Vena } \\
\text { jug. }\end{array}$ & 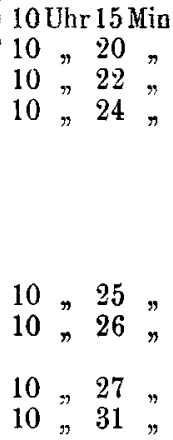 & $\mid \begin{array}{c}35,5 \\
35,2 \\
35,1 \\
-\end{array}$ & $\begin{array}{l}\text { Nach Freilegung d. Vene. } \\
\text { Nach der Injection. } \\
\text { 156Athemz., gleichmäss. } \\
\text { Athmung wird unregel- } \\
\text { mässig, Thier taumelt, } \\
\text { liegt auf der Seite, } \\
\text { Sprungkrämpfe ange- } \\
\text { deutet. Athmung ganz } \\
\text { selten, terminal. } \\
\text { GanzvereinzelteA themz. } \\
\text { Todt. Es quillt blutige } \\
\text { Flüssigk. a. d. Nüstern. } \\
\text { Das Herz schlägt noch. } \\
\text { Flimmern des Vorhofs. }\end{array}$ & $\begin{array}{l}\text { Lungen m.starken punkt- } \\
\text { u. flächenförmigen sub- } \\
\text { pleuralen Blutungen. } \\
\text { Von der Schnittfläche } \\
\text { quillt spontan reichlich } \\
\text { ödematöse Flüssigkeit. } \\
\text { Schnittfläche lässtneben } \\
\text { gering. Emphysem auch } \\
\text { geringe Blutungen er- } \\
\text { kennen. Keine Injec- } \\
\text { tionen d.inneren Organe. } \\
\text { Uebrige Section obne } \\
\text { Besonderheiten. }\end{array}$ \\
\hline
\end{tabular}




\begin{tabular}{|c|c|c|c|c|c|c|c|c|c|c|}
\hline 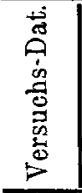 & 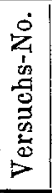 & 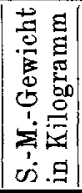 & 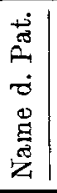 & 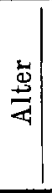 & 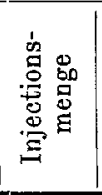 & 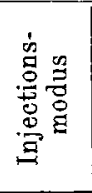 & Zeit & 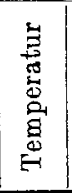 & Bemerkungen & Sectionsbefund \\
\hline 6.4 & 75 & 0,205 & K. & 47 & $0,5 \mathrm{~cm}$ & $\begin{array}{l}\text { Intra- } \\
\text { venös } \\
\text { Vena } \\
\text { jug. }\end{array}$ & 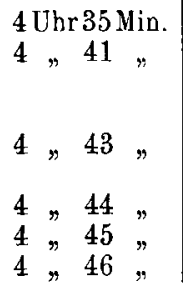 & $\mid \begin{array}{c}34,5 \\
33,1 \\
- \\
- \\
- \\
-\end{array}$ & $\begin{array}{l}\text { Nach Freilegung d.Vene. } \\
\text { Nach der Injection. Thier } \\
\text { schreit und wehrt sich } \\
\text { beim Losschneiden. } \\
\text { Tier liegt auf der Seite, } \\
\text { spärliche tiefe Athemz. } \\
\text { Terminale Athemzüge. } \\
\text { Todt. } \\
\text { Herz schlägt noch. }\end{array}$ & $\begin{array}{l}\text { Lungen mässiggedunsen. } \\
\text { Von der Schnittfläche } \\
\text { quillt schaumige blutige } \\
\text { Flüssigkeit. Starkes } \\
\text { Lungenödem. Mässiges } \\
\text { Emphysem. Neben- } \\
\text { nieren frei. }\end{array}$ \\
\hline
\end{tabular}

Diagnose: Carcinoma ventriculi.

\begin{tabular}{|c|c|c|c|c|c|c|c|c|c|}
\hline 2.8 . & 81 & 0,350 & S. & - & $1 \mathrm{ccm}$ & \begin{tabular}{|} 
Intra- \\
venös \\
Vena \\
jug.
\end{tabular} & 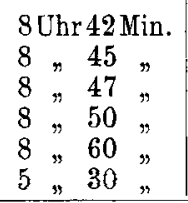 & $\begin{array}{l}37,0 \\
36,8 \\
- \\
- \\
- \\
37,5\end{array}$ & $\begin{array}{l}\text { Nach Freilegung d.Vene. } \\
\text { Nach der Injection. } \\
\text { Thier hat Zuckungen. } \\
\text { Thier liegt auf der Seite. } \\
\text { Hat sich wieder erholt. } \\
\text { Thier vollig munter. }\end{array}$ \\
\hline 2. 8 . & 82 & 0,335 & B. & - & $1 \mathrm{ccm}$ & $\begin{array}{c}\text { Intra- } \\
\text { venös } \\
\text { Vena } \\
\text { jug. }\end{array}$ & 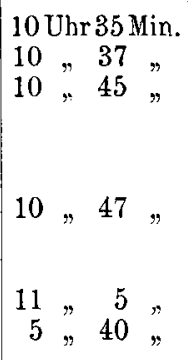 & $\begin{array}{c}35,8 \\
35,0 \\
34,8 \\
\\
35,8 \\
- \\
-\end{array}$ & $\begin{array}{l}\text { Nach Freilegung d.Vene. } \\
\text { Nach der Injection. } \\
\text { Thier hatSprungkrämpfe } \\
\text { und liegt auf der Seite, } \\
\text { Athmung sehr unregel- } \\
\text { mässig. } \\
\text { Thier liegt auf der Seite, } \\
\text { verlangsamte und ver- } \\
\text { tiefte Athmung. } \\
\text { Thier hat sich erholt. } \\
\text { Thier völlig munter. }\end{array}$ \\
\hline
\end{tabular}

In diesen Versuchen gelang es uns bisher nicht, eine erhöhte Giftigkeit der Sera gewisser Krankheitsgruppen nachuuweisen, für isolytische Sera speciell für Carcinomsera konnte ein abweichendes Verhalten nach irgend einer Richtung nicht festgestellt werden.

Wir hatten in erster Linie bei den im zweiten Theil unserer Arbeit mitgetheilten Untersuchungen im Auge, über die Natur der im Serum Krebskranker auftretenden hämolytischen Stoffe Aufschluss zu erhalten. Die klinische Verwerthbarkeit der hämolytischen Reactionen hatten für uns erst secundäres Interesse. Wir glauben, dass diese nach den Befunden anderer Autoren und unserer eigenen eine sehr bedingte ist. Die hämolytischen Versuche gegenüber artfremden Blutkörpern.[Kelling (16)] gaben wir bald wieder auf, da, wie von Dungern besonders hervorgehoben hat, die individuellen Schwankungen des Serums im Gehalt seiner natürlichen Hämolysine eben so grosse sind schon beim normalen Menschen, wie diejenigen, welche nach Kelling's Untersuchungen für maligne Geschwülste charakteristisch sein sollen, Wiederoe (17) findet nach der Kelling'schen Methode 64 pCt. positive Fälle und von 25 nicht an Carcinom und Sarkom leidenden Patienten 22 negative. Rosenbaum (18) glaubt in der Kelling'schen Methode ein Hülfsmittel für die Krebsdiagnose sehen zu dürfen, während Fischel (19) sich ablehnend 
verhält. Crile (20) war der erste, der sich mit dem Studium der Isohämolysine im Serum Krebskranker befasste, er fand nach der von ihm angebenen Methode bei 66 Fällen von malignen Tumoren 33 mal Isolysine. Richartz (21) fand im Blut von Carcinomatösen und Tuberculösen in 48 bezw. 52 pCt. aller Fälle Isolysine. Er glaubt, dass für manche Abdominalcarcinome das Auftreten von Isolysinen einen diagnostischen Hinweis abgeben könne. Zu einem ähnlichen Resultat kommen M. Weinberg und M. Mello (22); dagegen glaubt G. Bertone, dass der hämolytischen Reaction in der Diagnostik der bösartigen Geschwülste kein praktischer Werth zukommt.

Nach unsern eigenen Untersuchungen können wir nur sovjel behaupten, dass unter Ausschluss von Lues und Tuberculose der Nachweis eines kräftigen Isolysins bei gleichzeitig bestehender hochgradiger Anämie und bei absoluter Resistenz der Blutkörper des untersuchten Falles gegenüber anderen Carcinom-Hämolysinen für die Diagnose "Carcinom" ins Gewicht fällt, das Fehlen dieser serologischen Zeichen Anlass geben kann, eine Diagnose auf Carcinom $z u$ revidiren. Wir haben unter Berücksichtigung dieser serologischen Factoren mehrmals gegen die rein klinische Diagnose Recht behalten, insofern, als ein angenommenes Carcinom des Magens, wie die Obduction in vivo lehrte, nicht bestand. Ein Fall davon war eine perniciöse Anämie mit allen klinischen Zeichen des occulten Magencarcinoms und hochgradiger Anämie aber ohne Isolysine. Gerade bei Magencarcinom mit hochgradiger Anämie ist das Auftreten von Isolysinen im Blutserum wie Tabelle II lehrt, ein ziemlich constantes. Doch kommt nach dem Gesagten in diagnostischer Beziehung bei der Umständlichkeit der Methode und der grossen Zahl der nothwendigen Controlen der Nachweis von Isolysinen klinisch diagnostisch wohl kaum in Frage. Damit wird aber die biologische Bedeutung dieser Befunde keineswegs berührt. Es bleibt weiterhin die Frage offen, ob diese Isolysine mit dem Krebsproblem an sich etwas zu thun haben, welche Bedingungsn ihr Auftreten begünstigen oder verhindern, ob sie Reactionsproducte des Körpers des Krebsträgers darstellen oder" als Zerfallsproducte von Carcinomgewebe aufzufassen sind, die durch Resorption in die Blutbahn gelangend im Serum nachweisbar werden.

Zusammenfassend kann gesagt werden, dass nach unseren vorwiegend aus klinischen Erwägungen angestellten Untersuchungen, der Körper nur äusserst selten durch von in ihm erzeugte hämolytisch wirksame Substanzen seinen Bestand an Blutkörpern schädigt. Mit Ausnahme der zwei Eingangs erwähnten Fälle waren stets nur Iso- nicht Autolysine gefunden worden. 


\section{Literaturverzeichniss.}

1. Noguchi, Biochemische Zeitschr. 1907. Bd. 6. S. 327.

2. Tarrasewitz, Annales de l'institut Pasteur. 1902. 16.

3. Friedemann, Deutsche ned. Wochenschr. 1907. S. 595.

4. K ̈̈lbs, Arch. f. exp. Pathologie u. Pharm. 1907. Bd. 55.

5. Bloch, Biochemische Zeitschr. 1908. Bd. 9. S. 498.

6. Grafe und Römer, Arch. f. klin. Med. 1909. Bd. 96. S. 397.

7. Dieselben, Ebenda. 1908. Bd. 93/94.

8. Berger und Tsuchiya, Deutsches Arch. f. klin. Med. 1909. Bd. 96. S. 252.

9. Donath und Landsteiner, Münch. med. Wochenschr. 1904.

10. Dieselben, Zeitschr. f. klin. Med. 1906. Bd. 58. S. 172.

11. von Dungern und Hirsch feld, Zeitschr. f. Immunitätsforsch. Bd. 8. S. 566.

12. Meyer und Emmerich, Arch. f. klin. Med. Bd. 96. S. 286.

13. Mora, Noda und Benjamin, Münch. med. Wochenschr. 1909. No. 11.

14. Grafe und Leo Müller, Arch. f. exp. Pathol. u. Pharm. Bd. 59.

15. Blasi, Dante do, Real. Acc. med. di Roma. 1908.

16. Kelling, Zeitschr. f. Krebsforsch. Bd. 6. S. 315 .

17. Wideroe, Norsk Magaz. for Lägevidenskaben. 1908. S. 118.

18. Rosenbaum, Münch. med. Wochenschr. 1908. No. 9. S. 443.

19. Fis c hel, Berl. klin. Wochensohr. 1908. No. 18. S. 882.

20. Crile, Journ. Am. Med, Assoc. Vol, 51. p. 138.

21. Richards, Dentsche med. Wochenschr. 1909. No. 31. S. 1340.

22. Weinberg und Mello, C. R. de la Soc. de Biol. T'. 67. p. 434, 441.

23. Faust und Talquist, Zeitschr. f. klin. Med. 1907. Bd. 61 u. Arch. f. exp. Pathol. u. Pharm. 1907. Bd. 57. S. 367.

24. Ehrlich, Berl. klin. Wochenschr. 1900. No. 21.

25. Moss, Fol. serol. 1910. Bd. 5. H. 3.

26. Steyskal, K., Wien. klin. Wochenschr. 1910. No.19. S.161 u. No.49. S.1701.

27. Guillain, Larosche, C. R. de la Soc. biol. T. CXIII. p. 246.

28. Tschernogubou, Deutsche med. Wochenschr. 1909. No. 15.

29. Noguchi, Münch. med. Wochenschr. 1909. No. 10.

30. Salkowski, Berliner klin. Wochenschr. 1905. S. 1580, 1618 und 1910. S. 533, $1746,2297$.

31. A. Schminke und F. Flury, Arch. f. exp. Path. u. Pharm. Bd. 64.

\section{Anhang.}

T a b e 11 e I.

Auf Hämolysine gegenüber Menschenblutkörperchen untersuchte Fälle.

\begin{tabular}{|c|c|c|c|c|c|}
\hline \multirow{2}{*}{ Diagnose } & \multirow{2}{*}{$\begin{array}{c}\text { Zahl } \\
\text { der Fälle }\end{array}$} & \multicolumn{2}{|c|}{ Hämolytisch } & \multirow{2}{*}{$\begin{array}{c}\text { Nicht } \\
\text { hämolytiseh }\end{array}$} & \multirow{2}{*}{$\begin{array}{c}\text { In Procenten } \\
\text { der Gesammt- } \\
\text { zahl }\end{array}$} \\
\hline & & stark & schwach & & \\
\hline Carcinom $\cdot . \cdot \therefore: \therefore$. & 43 & 16 & 5 & 30 & 48,8 \\
\hline 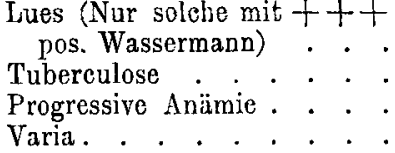 & $\begin{array}{r}182 \\
25 \\
3 \\
69\end{array}$ & $\begin{array}{r}11 \\
4 \\
3 \\
10\end{array}$ & $\frac{4}{3}$ & $\begin{array}{r}167 \\
9 \\
- \\
53\end{array}$ & $\begin{array}{c}8,33 \\
28,5 \\
(100,0) \\
23,2\end{array}$ \\
\hline
\end{tabular}


T a b e lle II.

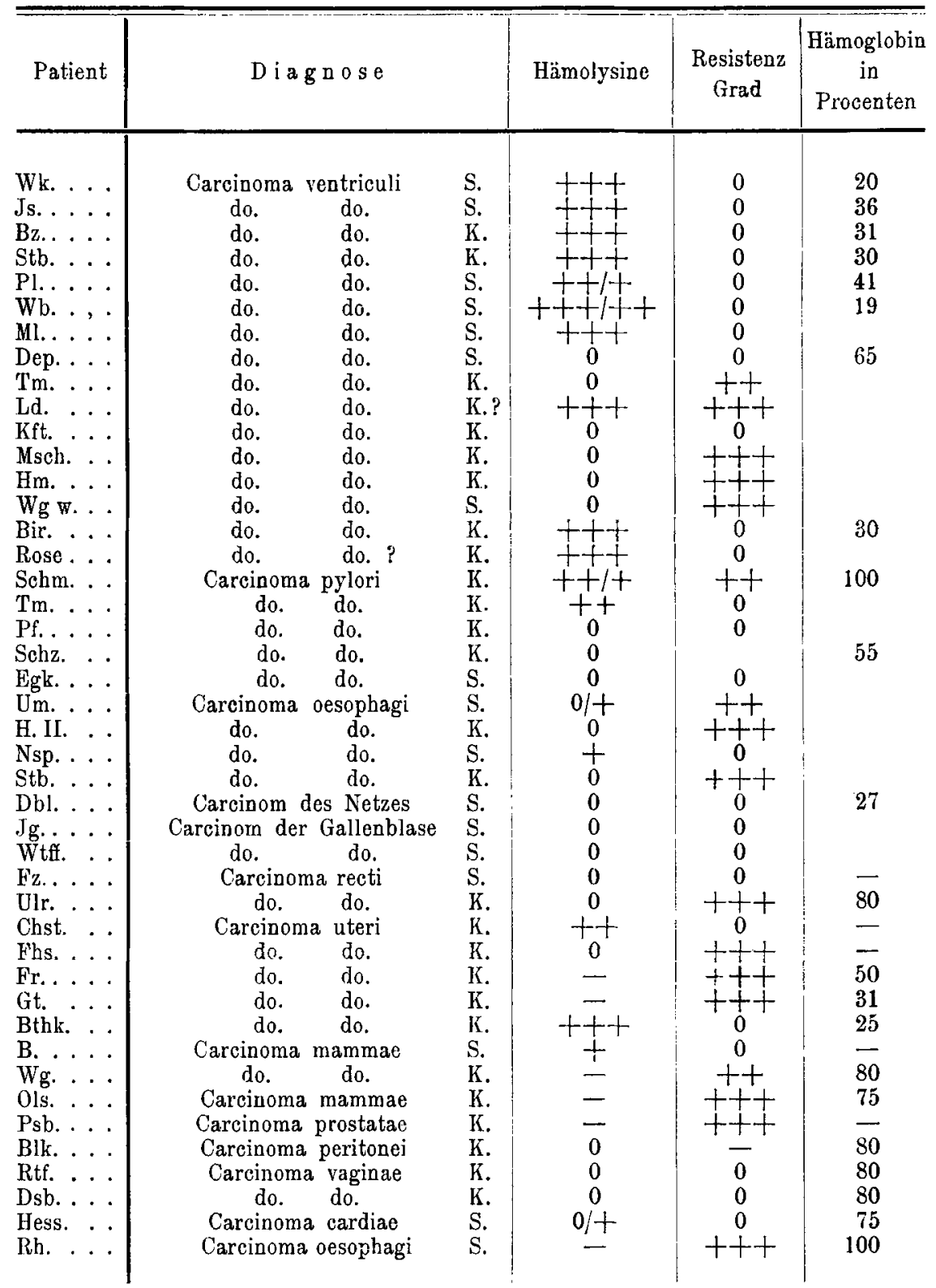

Bezeichnung der Abkürzungen:

K. = Diagnose, durch klinische Untersuchung festgestellt.

S. = Diagnose, durch die Section festgestellt.

$+++=$ stark lösend in Rubrik 3 .

$+++=$ stark gelöst in Rubrik 4 .

$0=$ nicht lösend in Rubrik 3 .

$0=$ nicht gelöst $(=$ resistent $)$ in Rubrik 4 . 
Tabelle III.

\section{Resistenz der rothen Blntkörperchen Carcinomkranker gegen hämolytische Carcinomsera.}

Versuch No. 144.

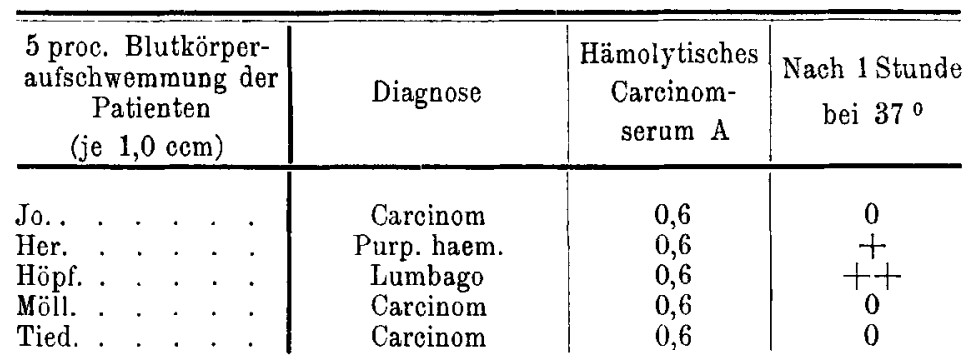

Versuch No. 14j.

\begin{tabular}{l|c|c|c}
\hline $\begin{array}{c}\text { 5 proc. Blutkörper- } \\
\text { aufschwemmung der } \\
\text { Patienten } \\
\text { (je 1,0 ccm) }\end{array}$ & Diagnose & $\begin{array}{c}\text { Hämolytisches } \\
\text { Carcinom- } \\
\text { serum B }\end{array}$ & $\begin{array}{c}\text { Nach 1 Stunde } \\
\text { bei } 37^{\circ}\end{array}$ \\
\hline Jo.. . . . . . & Carcinom & 1,0 & 0 \\
Her. . . . . . & Purp. haem. & 1,0 & + \\
Höpf. . . . . . & Lumbago & 1,0 & + \\
Möll. . . . . . & Carcinom & 1,0 & 0 \\
Tied. . . . . . . & Carcinom & 1,0 & 0
\end{tabular}

Versuch No. 214.

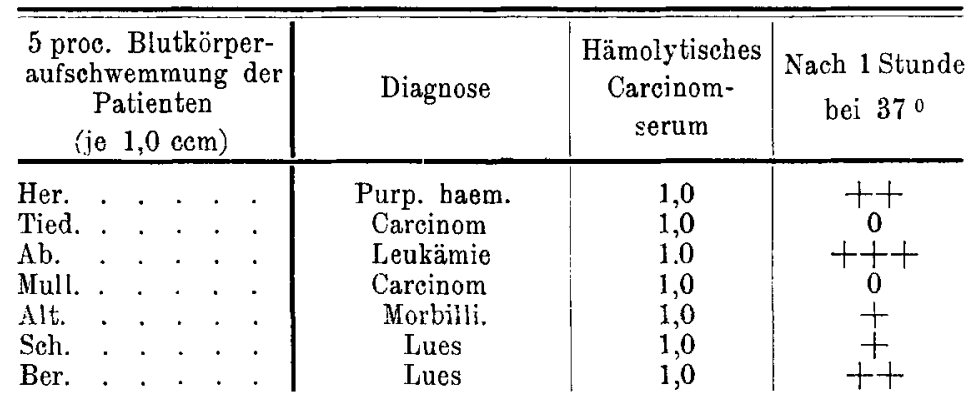

Versuch No. 229.

\begin{tabular}{|c|c|c|c|}
\hline $\begin{array}{c}5 \text { proc. Blutkörper- } \\
\text { aufschwemmung der } \\
\text { Patienten } \\
\text { (je } 1,0 \mathrm{ccm}) \\
\end{array}$ & Diagnose & $\begin{array}{l}\text { Hämolytisches } \\
\text { Carcinom- } \\
\text { serum }\end{array}$ & $\begin{array}{c}\text { Nach } 1 \text { Stunde } \\
\text { bei } 37^{\circ}\end{array}$ \\
\hline 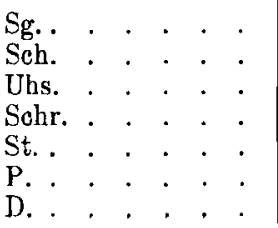 & $\begin{array}{l}\text { Normal } \\
\text { Lues } \\
\text { Carcinom } \\
\text { Carcinom } \\
\text { Lues } \\
\text { Carcinom } \\
\text { Tabes }\end{array}$ & $\begin{array}{l}1,0 \\
1,0 \\
1,0 \\
1,0 \\
1,0 \\
1,0 \\
1,0\end{array}$ & $\begin{array}{l}++ \\
+ \\
0 \\
0 \\
+ \\
0 \\
+\end{array}$ \\
\hline
\end{tabular}


Ueber Iso- und Autohämolysine im menschlichen Blutserum.

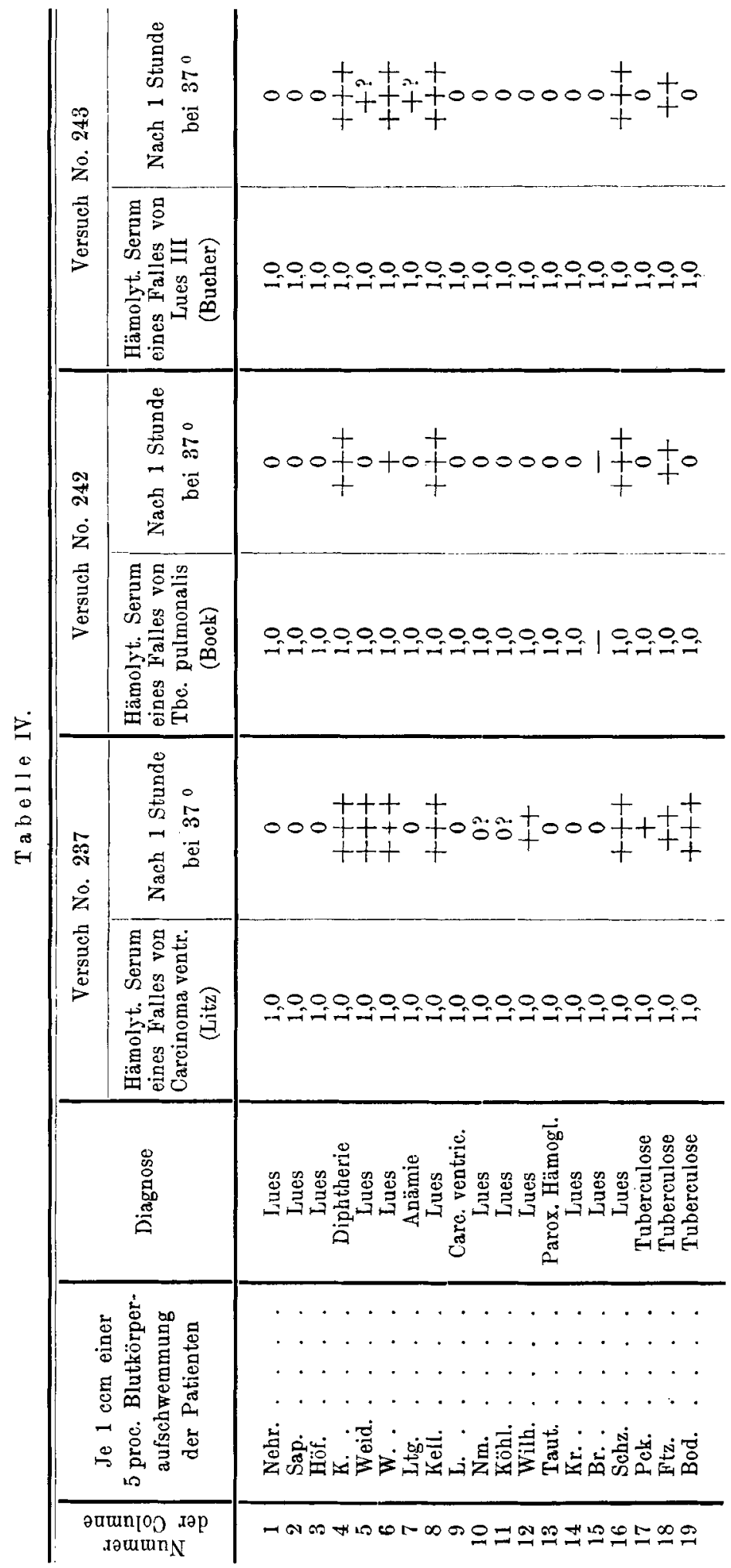




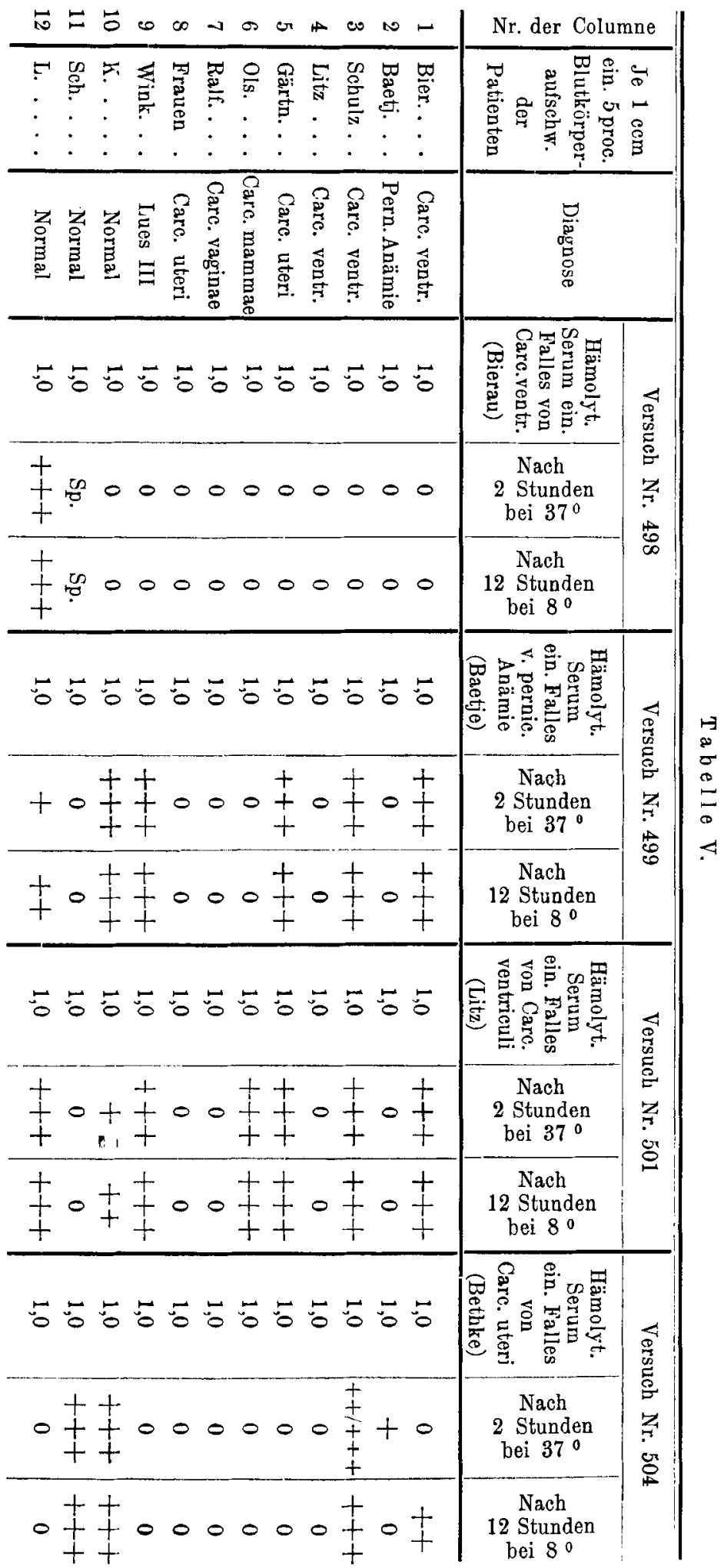


T a b e lle VI.

\begin{tabular}{|c|c|c|c|c|}
\hline $\begin{array}{l}5 \text { proc. Aufschwem- } \\
\text { mung von Normal- } \\
\text { Blutkörpern } \\
\text { je } 1 \text { cem }\end{array}$ & $\begin{array}{l}\text { Hämolytisches } \\
\text { Serum von } \\
\text { Carcinom I }\end{array}$ & $\begin{array}{l}\text { Hämolytisches } \\
\text { Serum von } \\
\text { Carcinom II }\end{array}$ & $\mathrm{NaCl}$. & $\begin{array}{l}\text { Nach } \\
2 \text { Stunden } \\
\text { bei } 37^{\circ}\end{array}$ \\
\hline 1,0 & 0,5 & 0,5 & - & +++ \\
\hline 1,0 & 0,5 & 0,3 & 0,2 & $+t+$ \\
\hline 1,0 & $0, \dot{\jmath}$ & 0,1 & 0,4 & $+t+$ \\
\hline 1,0 & - & - & 1,5 & - \\
\hline $\begin{array}{l}5 \text { proc. Aufsehwem- } \\
\text { mung von Normal- } \\
\text { Blutkörpern } \\
\text { je } 1 \mathrm{ccm}\end{array}$ & $\begin{array}{c}\text { Hämolytisches } \\
\text { Serum } \\
\text { von Carcinom }\end{array}$ & $\begin{array}{l}\text { Nicht hämo- } \\
\text { lytisches } \\
\text { Normalserum }\end{array}$ & $\mathrm{NaCl}$. & $\begin{array}{c}\text { Nach } \\
2 \text { Stunden } \\
\text { bei } 37^{\circ}\end{array}$ \\
\hline 1,0 & 0,5 & 0,5 & - & 0 \\
\hline 1,0 & 0,5 & 0,3 & 0,2 & 0 \\
\hline 1,0 & 0,5 & 0,1 & 0,4 & + \\
\hline 1,0 & 0,5 & - & 0,5 & $+t+$ \\
\hline
\end{tabular}

Tabelle VII.

Kälteeinwirknng anf die hämolytische Kraft der Sera.

Versuch No. 140.

\begin{tabular}{c|c|c|c|c}
\hline $\begin{array}{c}\text { 5 proc. Normal- } \\
\text { Blutkörper }\end{array}$ & $\begin{array}{c}\text { Je 1 cem } \\
\text { Serum des } \\
\text { Patienten }\end{array}$ & Diagnose & $\begin{array}{c}\text { Nach } \\
\text { 2 Stunden } \\
\text { bei 370 }\end{array}$ & $\begin{array}{c}\text { Nach } \\
\text { Stunden } \\
\text { bei 370 }\end{array}$ \\
\hline 1,0 & Joh. & Carcinoma ventric. & ++++ & ++++ \\
1,0 & Schü. & Carcinoma pylori & +++ & +++ \\
1,0 & Möller & Carcinoma ventric. & ++ & ++ \\
1,0 & Tied. & Carcinoma pylori & ++ & ++ \\
1,0 & $\mathrm{NaCl}$ & - & 0 & 0
\end{tabular}

Versuch No. 141. (Blutkïrper-Serumgemische wie in No. 140, aber vor der Bebreitung

\begin{tabular}{c|c|c|c|c}
\multicolumn{3}{c|}{$1 / 2$ Stunde bei $0^{\circ}$ gehalten.) } \\
\hline 1,0 & Joh. & Carcinoma ventric. & + & + \\
1,0 & Schü. & Carcinoma pylori & 0 & 0 ? \\
1,0 & Möller & Carcinoma ventric. & 0 & 0 ? \\
1,0 & Ticd. & Carcinoma pylori & 0 & 0 ? \\
1,0 & NaCl & - & 0 & 0
\end{tabular}


Tabelle VIII.

Versuch No. 396.

\begin{tabular}{|c|c|c|c|c|c|c|c|c|c|c|}
\hline $\begin{array}{l}\text { Je } 1 \text { ccm einer } 5 \text { proc. } \\
\text { Blutkörperauf- } \\
\text { schwemmung d. Pat.: }\end{array}$ & 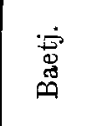 & 崩 & 总 & 它 & 式 & 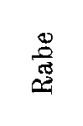 & 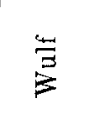 & $\begin{array}{l}0 \\
\frac{0}{0} \\
0 \\
0 \\
0\end{array}$ & 怘 & 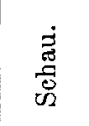 \\
\hline Diagnose & Anäm. & $\begin{array}{l}\text { Carc. } \\
\text { vagin. }\end{array}$ & Lues & Tbeul. & Lues & Carc.? & Sepsis & $\begin{array}{l}\text { Carc. } \\
\text { ventr. }\end{array}$ & $\begin{array}{l}\text { Carc. } \\
\text { ventr. }\end{array}$ & Tbcul. \\
\hline $\begin{array}{l}\text { Serum eines Falles von } \\
\text { Ca. ventr. (Stobbe) }\end{array}$ & 1,0 & 1,0 & 1,0 & 1,0 & 1,0 & 1,0 & 1,0 & 1,0 & 1,0 & 1,0 \\
\hline Nach 2 Std. bei $37^{\circ}$ & 0 & 0 & $t+t$ & 0 & 0 & $+t+$ & +++ & 0 & 0 & $t+t$ \\
\hline Nach 12 Std. bei $8^{0}$ & 0 & 0 & c & 0 & 0 & $t+t$ & $t+t$ & 0 & 0 & $+t \cdot t$ \\
\hline
\end{tabular}

Versuch No. 397.

Serum eines Falles von Anäm.progr.(Baetje)

Nach 2 Std. bei $37^{\circ}$

Nach 12 Std. bei $8^{\circ}$

\begin{tabular}{|c|c|c|c|c|c|c|c|c|c} 
& & & & & & & & & \\
1,0 & 1,0 & 1,0 & 1,0 & 1,0 & 1,0 & 1,0 & 1,0 & 1,0 & 1,0 \\
0 & 0 & +++ & 0 & 0 & +++ & +++ & 0 & 0 & +++ \\
0 & 0 & $c$ & 0 & 0 & $c$ & $c$ & 0 & 0 & $c$
\end{tabular}

Versuch No. 393.

\begin{tabular}{l|c|c|c|c|c|c|c|c|c|c}
\hline Saponinverd. 1:30000 & 1,0 & 1,0 & 1,0 & 1,0 & 1,0 & 1,0 & 1,0 & 1,0 & 1,0 & 1,0 \\
Nach 2 Std. bei 370 & 0 & +++ & +++ & 0 & ++ & 0 & +++ & 0 & 0 & + \\
Nach 12 Std. bei 8 0 & 0 & c & c & 0 & +++ & 0 & $c$ & 0 & 0 & ++
\end{tabular}

Versuch No. 395.

\begin{tabular}{l|c|c|c|c|c|c|c|c|c|c}
\hline Saponinverd. 1:50000 & 1,0 & 1,0 & 1,0 & 1,0 & 1,0 & 1,0 & 1,0 & 1,0 & 1,0 & 1,0 \\
Nach 2 Std. bei 370 & 0 & +++ & +++ & 0 & ++ & 0 & +++ & 0 & 0 & + \\
Nach 12 Std. bei 80 & 0 & $\mathrm{c}$ & $\mathrm{c}$ & 0 & +++ & 0 & $\mathrm{c}$ & 0 & 0 & ++
\end{tabular}

Versuch No. 386.

\begin{tabular}{l|c|c|c|c|c|c|c|c|c|c}
\hline Oelsäureverd. 1:16000 & 1,0 & 1,0 & 1,0 & 1,0 & 1,0 & 1,0 & 1,0 & 1,0 & 1,0 & 1,0 \\
Nach 2 Std. bei 370 & 0 & 0 & ++ & $\mathrm{c}$ & +++ & 0 & 0 & 0 & 0 & ++ \\
Nach 12 Std. bei 8 & 0 & 0 ? & +++ & $\mathrm{c}$ & +++ & 0 & 0 & 0 & 0 & ++
\end{tabular}

Versuch No. 387.

\begin{tabular}{c|c|c|c|c|c|c|c|c|c|c}
\hline Oelsäureverd.1:18000 & 1,0 & 1,0 & 1,0 & 1,0 & 1,0 & 1,0 & 1,0 & 1,0 & 1,0 & 1,0 \\
Nach 2 Std. bei 370 & 0 & 0 & ++ & ++ & +++ & 0 & 0 & 0 & 0 & ++ \\
Nach 12 Std. bei 8 & 0 & 0 & +++ & $c$ & +++ & 0 & 0 & 0 & 0 & ++
\end{tabular}

Versuch No. 390.

\begin{tabular}{l|c|c|c|c|c|c|c|c|c|c}
\hline Natr. ol.Verd. 1:6000 & 1,0 & 1,0 & 1,0 & 1,0 & 1,0 & 1,0 & 1,0 & 1,0 & 1,0 & 1,0 \\
Nach 2 Std. bei 37 & 0 & 0 & +++ & $\mathrm{c}$ & ++ & 0 & 0 & $0 ?$ & 0 & ++ \\
Nach 12 Std. bei $8^{\circ}$ & 0 ? & 0 & $\mathrm{c}$ & $\mathrm{c}$ & +++ & 0 & 0 & 0 ? & 0 & $\mathrm{e}$
\end{tabular}

Versuch No. 391.

\begin{tabular}{l|c|c|c|c|c|c|c|c|c|c}
\hline Natr. 0l.Verd. 1:8000 & 1,0 & 1,0 & 1,0 & 1,0 & 1,0 & 1,0 & 1,0 & 1,0 & 1,0 & 1,0 \\
Nach 2 Std. bei 370 & 0 & 0 & +++ & +++ & Sp. & 0 & 0 & 0 & 0 & ++ \\
Nach 12 Std. bei 8 & 0 & 0 & $\mathrm{c}$ & +++ & Sp. & 0 & 0 & 0 & 0 & $\mathrm{c}$
\end{tabular}


Ueber Iso- und Autohämolysine im menschlichen Blutserum.

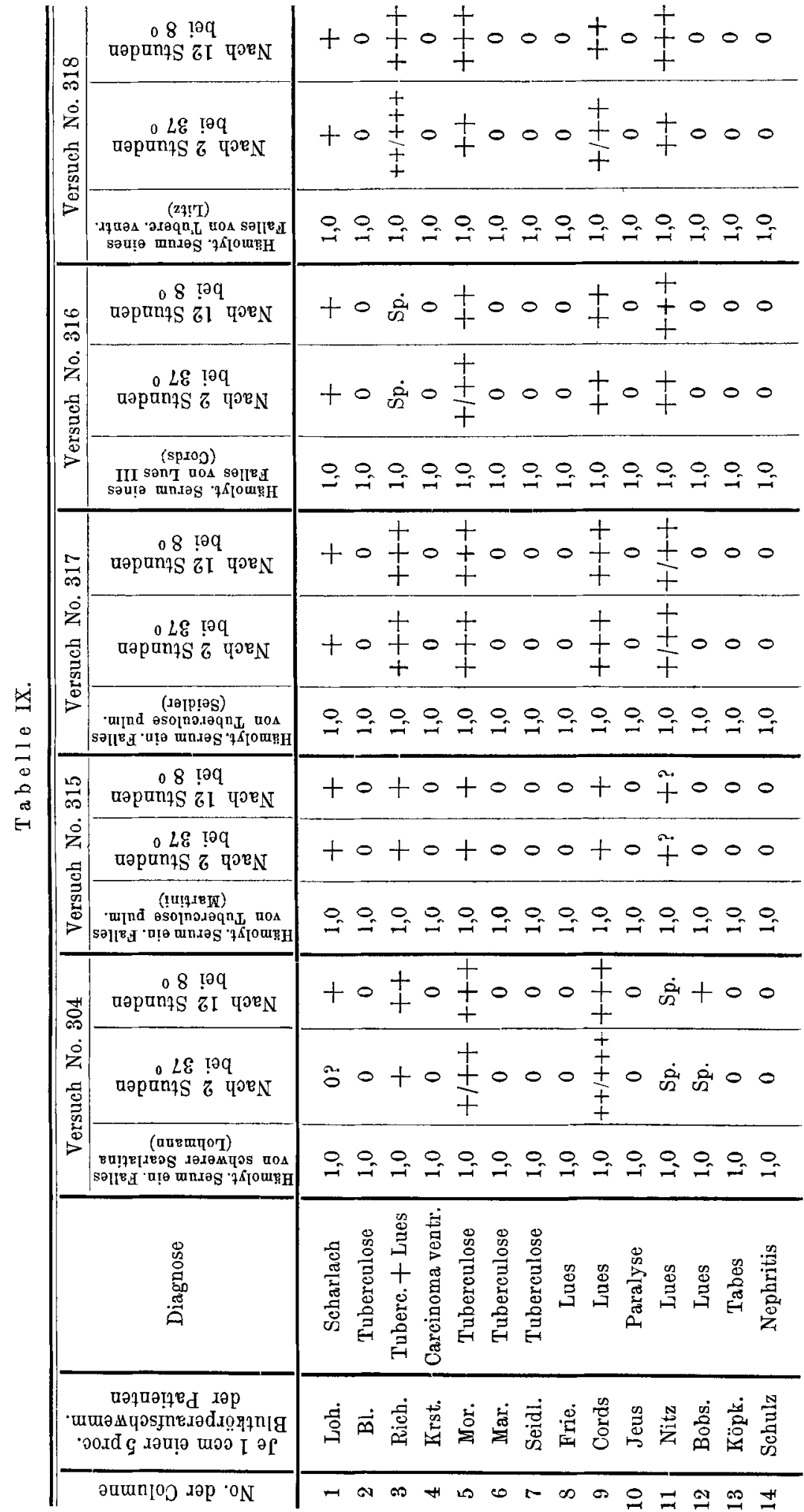




\begin{tabular}{|c|c|c|}
\hline 10 & \multicolumn{2}{|l|}{ Name der Columne } \\
\hline 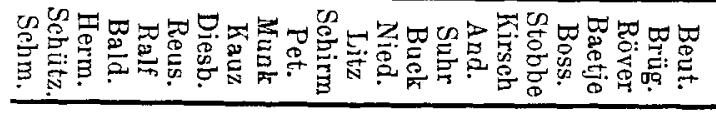 & $\begin{array}{c}\text { Je } 1 \text { cem einer } 5 \text { pr } \\
\text { Blutkörperaufschwem } \\
\text { der Patienten }\end{array}$ & \\
\hline 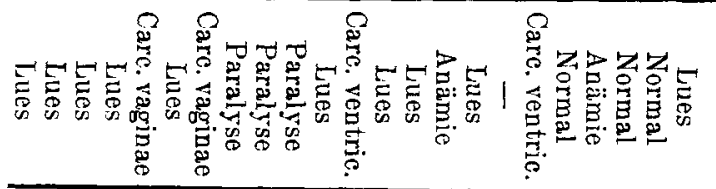 & 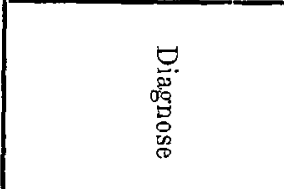 & \\
\hline 0505050050505050 & $\begin{array}{c}\text { Humol. Serum eines ralles } \\
\text { ron Carc. ventr. (Stobbe) }\end{array}$ & 4 \\
\hline$\frac{ \pm+}{+}++$ & $\begin{array}{l}\text { Nach } 2 \text { Stunden } \\
\text { bei } 37^{\circ}\end{array}$ & $\left|\begin{array}{c}3 \\
0 \\
0 \\
0 \\
0 \\
z \\
z\end{array}\right|$ \\
\hline$\stackrel{+}{+}++$ & $\begin{array}{c}\text { Nahh } 12 \text { Stunden } \\
\text { bei } 8^{\circ}\end{array}$ & 崮 \\
\hline 50000505000 & $\begin{array}{c}\text { Hrmol. Serumeines Falles } \\
\text { von Care. ventr. (Litz) }\end{array}$ & $\mid$ \\
\hline $0000000 t$ & $\begin{array}{l}\text { Nach } 2 \text { Stunden } \\
\text { bei } 37^{\circ}\end{array}$ & $\left|\begin{array}{ccc}2 \\
\vdots \\
\vdots \\
z\end{array}\right|$ \\
\hline 00000001 & $\begin{array}{l}\text { Nach } 12 \text { Stunden } \\
\text { bei } 8^{\circ}\end{array}$ & : \\
\hline 60500000 & $\begin{array}{l}\text { Hämol. Serum eines Falles } \\
\text { von pernic. Anäm. (Baetje) }\end{array}$ & 8 \\
\hline ootooto & $\begin{array}{l}\text { Nach } 2 \text { Stimden } \\
\text { bei } 37^{\circ}\end{array}$ & 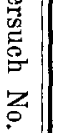 \\
\hline 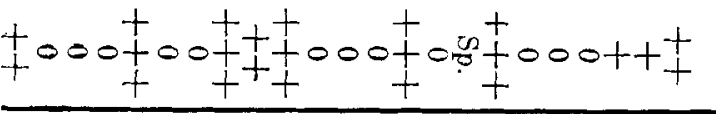 & Nach 12 Stunden & $\begin{array}{ll}\mathscr{L} \\
\check{\sigma}\end{array}$ \\
\hline 500000055050000500005050000 & \begin{tabular}{|c|} 
Saponin Verdünnung \\
$1: 50000$
\end{tabular} & $\overrightarrow{9}$ \\
\hline $\begin{array}{c}00000000000000+000+t+000 \\
t+t\end{array}$ & $\begin{array}{l}\text { Nach } 2 \text { Stunden } \\
\text { bei } 37^{\circ}\end{array}$ & 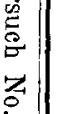 \\
\hline 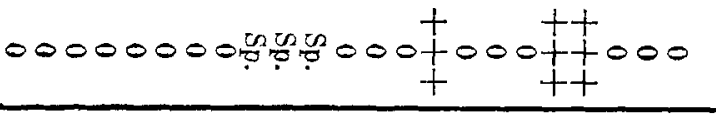 & $\begin{array}{l}\text { Nach } 12 \text { Stunden } \\
\text { bei } 8^{\circ}\end{array}$ & 然 \\
\hline 00500000000000005000050005000 & $\begin{array}{l}\text { Oelsäure-Verdünnung } \\
1: 15000\end{array}$ & 我 \\
\hline 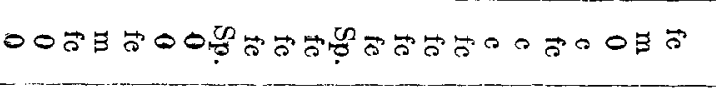 & $\begin{array}{c}\text { Nach } 2 \text { Stunden } \\
\text { bei } 37^{\circ}\end{array}$ & $\begin{array}{l}\frac{5}{5} \\
\vdots \\
z \\
0\end{array}$ \\
\hline 00 它的 000 贶 & $\begin{array}{l}\text { Nach } 12 \text { Stunden } \\
\text { bei } 8^{0}\end{array}$ & 唯 \\
\hline 0500500050005050050005050500 & $\begin{array}{l}\text { Natr. oleat. Ver- } \\
\text { dünnung } 1: 90000\end{array}$ & $\overline{9}$ \\
\hline $000000000 \frac{0}{1} 000000000000$ & $\begin{array}{c}\text { Nach } 2 \text { Stunden } \\
\text { bei } 37^{\circ}\end{array}$ & $\begin{array}{l}0 \\
\text { z } \\
z \\
0\end{array}$ \\
\hline 00000 & $\begin{array}{c}\text { Nach } 12 \text { Stunden } \\
\text { bei } 8^{\circ}\end{array}$ & d \\
\hline
\end{tabular}


Tabe Ile XI.

\begin{tabular}{|c|c|c|c|c|c|c|c|}
\hline $\begin{array}{l}\text { Unter- } \\
\text { suchungs- } \\
\text { tage }\end{array}$ & Name & Diagnose & $\begin{array}{l}\text { Serologisches } \\
\text { Verhalten }\end{array}$ & $\begin{array}{c}\text { Ge- } \\
\text { sammt- } \\
\mathrm{N} .\end{array}$ & $\begin{array}{c}\text { Kol- } \\
\text { loidal- } \\
\text { N. }\end{array}$ & $\begin{array}{l}\text { Koll.-N } \\
\text { in } \% . \\
\text { Ges. }-\mathrm{N}\end{array}$ & $\begin{array}{l}\text { Bemer- } \\
\text { kungen }\end{array}$ \\
\hline $\begin{array}{l}\text { I. Tag } \\
\text { II. Tag } \\
\text { III. Tag }\end{array}$ & Litz & Carcin. ventriculi & $\begin{array}{c}\text { Stark wirksam. } \\
\text { lsolysin }\end{array}$ & $\begin{array}{l}11,17 \\
12,85 \\
14,42\end{array}$ & $\begin{array}{l}1,02 \\
1,08 \\
1,31\end{array}$ & $\begin{array}{l}9,20 \\
8,40 \\
9,10\end{array}$ & \\
\hline $\begin{array}{l}\text { I. Tag } \\
\text { II. Tag } \\
\text { III. Tag }\end{array}$ & Ohlsen & Carcin. mamme & Kein Isolysin & $\begin{array}{r}10,28 \\
10,76 \\
9,88\end{array}$ & $\begin{array}{l}0,17 \\
0,29 \\
0,35\end{array}$ & $\begin{array}{l}1,6 \\
2,7 \\
3,6\end{array}$ & \\
\hline I. Tag & Ralf & Carcin. vaginae & Kein Isolysin & 6,83 & 0,21 & 3,2 & \\
\hline $\begin{array}{l}\text { I. Tag } \\
\text { II. Tag }\end{array}$ & Frauen & Carcin. uteri & Kein Isolysin & $\begin{array}{l}2,53 \\
2,78^{*}\end{array}$ & $\begin{array}{l}0,19 \\
0,09\end{array}$ & $\begin{array}{l}7,7 \\
3,3\end{array}$ & $\begin{array}{l}\text { hochgrad. } \\
\text { Kachexio }\end{array}$ \\
\hline $\begin{array}{l}\text { I. Tag } \\
\text { II. Tag } \\
\text { III. Tag } \\
\text { IV. Tag }\end{array}$ & Bierau & Carcin. ventriculi & $\begin{array}{c}\text { Stark wirksam. } \\
\text { Isolysin }\end{array}$ & $\begin{array}{l}5,73 \\
\\
5,90 \\
5,18 \\
6,03\end{array}$ & $\begin{array}{l}0,68 \\
\\
0,75 \\
0,33 \\
0,32\end{array}$ & $\begin{array}{r}11,9 \\
12,6 \\
6,3 \\
5,2\end{array}$ & \\
\hline $\begin{array}{l}\text { I. Tag } \\
\text { II. Tag } \\
\text { III. Tag }\end{array}$ & Schultz & Carcin. pylori & Kein Isolysin & $\begin{array}{l}5,39 \\
5,55 \\
5,52\end{array}$ & $\begin{array}{l}0,16 \\
0,20 \\
0,28\end{array}$ & $\begin{array}{l}3,0 \\
3,8 \\
5,2\end{array}$ & \\
\hline $\begin{array}{l}\text { I. Tag } \\
\text { II. Tag }\end{array}$ & $\begin{array}{l}\text { Nieder- } \\
\text { meier }\end{array}$ & $\begin{array}{l}\text { Carcin. ventriculi } \\
\text { Lues III }\end{array}$ & Kein Isolysin & $\begin{array}{l}5,80 \\
4,47\end{array}$ & $\begin{array}{l}0,31 \\
0,28\end{array}$ & $\begin{array}{l}5,3 \\
6,3\end{array}$ & \\
\hline
\end{tabular}

* Die sehr niedrigen Gesammt-N.-Werthe sind dadurch bedingt, dass Urin verloren ging.

Anmerkung: Sämmtliche untersuchten Fälle wurden an 6 Tagen nur mit Eiern, Weissbrot, Butter und Milch ernährt. Erst vom 4. Tage ab wurden die Bestimmungen durchgefựhrt. 